IZA DP No. 8714

Following the Crowd:

Leisure Complementarities Beyond the Household

Simon Georges-Kot

Dominique Goux

Eric Maurin

December 2014 


\title{
Following the Crowd: Leisure Complementarities Beyond the Household
}

\author{
Simon Georges-Kot \\ INSEE \\ Dominique Goux \\ CREST \\ Eric Maurin \\ PSE and IZA
}

Discussion Paper No. 8714

December 2014

\author{
IZA \\ P.O. Box 7240 \\ 53072 Bonn \\ Germany \\ Phone: +49-228-3894-0 \\ Fax: +49-228-3894-180 \\ E-mail: iza@iza.org
}

\begin{abstract}
Any opinions expressed here are those of the author(s) and not those of IZA. Research published in this series may include views on policy, but the institute itself takes no institutional policy positions. The IZA research network is committed to the IZA Guiding Principles of Research Integrity.

The Institute for the Study of Labor (IZA) in Bonn is a local and virtual international research center and a place of communication between science, politics and business. IZA is an independent nonprofit organization supported by Deutsche Post Foundation. The center is associated with the University of Bonn and offers a stimulating research environment through its international network, workshops and conferences, data service, project support, research visits and doctoral program. IZA engages in (i) original and internationally competitive research in all fields of labor economics, (ii) development of policy concepts, and (iii) dissemination of research results and concepts to the interested public.
\end{abstract}

IZA Discussion Papers often represent preliminary work and are circulated to encourage discussion. Citation of such a paper should account for its provisional character. A revised version may be available directly from the author. 
IZA Discussion Paper No. 8714

December 2014

\section{ABSTRACT \\ Following the Crowd: Leisure Complementarities Beyond the Household ${ }^{*}$}

Leisure externalities across households have potentially very important implications for labor market regulations, but they have proven difficult to identify. This paper exploits the unique features of school holidays and regulations about paid leave in France to identify how changes in the timing of work and leisure activities for individuals living with children affect the time use decisions of individuals living in other households. We find that exogenous increases in holidays for individuals living with children actually induce very significant increases in the demand for holidays from individuals living in other households. These positive interactions across households are all the more striking as exogenous increases in the number of individuals on holidays are also shown to be associated with very significant increases in the costs of holidays.

JEL Classification: J22, D62

Keywords: $\quad$ social interactions, leisure demand, paid leave, school holidays

Corresponding author:

Eric Maurin

Paris School of Economics

$48 \mathrm{Bd}$ Jourdan

75014 Paris

France

E-mail: eric.maurin@ens.fr

\footnotetext{
* We would like to thank Philippe Askenazy, Sandra Black, Daniel Hamermesh and Sandra McNally for helpful discussions as well as participants at seminars given at UC3M (Madrid), HECER (Helsinki), University of Surrey, University of Texas at Austin, Paris School of Economics, CREST, INSEE. We would also like to thank the organizers and participants at the conference on the Frontier of Time Use Research in Paris (May, 2014).
} 


\section{Introduction}

Externalities in time use decisions have long been regarded as a central issue in the economic literature. When an individual's demand for leisure depends on that of others, a local reduction in hours worked in some specific industries or occupations can lead to an economy-wide decrease in aggregate labour supply. More generally, externalities in time use have deep implications for the role of unions and regulations. When individuals derive utility from synchronizing their work and leisure activities with those of others, societies which impose a higher degree of coordination in market and non-market activities may find themselves better off in aggregate.

Despite the potential importance of externalities in time use decisions, there is still little evidence on their actual magnitude. In particular, there are very few economic studies on whether the time use decisions of an individual are affected by those of individuals living in other households. Progress in these directions has been impaired by the difficulty of identifying independent variation in time use decisions for specific groups of households, in specific areas, as households living in the same area are typically exposed to the same seasonal variation in the determinants of work and leisure activities. Also, households living in the same economic area are generally constrained by the same working time regulations and the same local labour demand shocks. In such a context, they tend to enjoy similar amounts of leisure at about the same time (e.g. Christmas period), but it does not follow that they find it more pleasurable to engage in leisure time at the same time as everybody else.

In this paper, we exploit the unique features of school holidays and paid leave regulations in France to overcome these issues. We show how independent changes in the 
timing of work and leisure activities for a specific group of individuals affect the time use decisions of individuals living in other households in the same region as well as in more distant places. We also provide evidence that these cross effects are mostly driven by complementarities in non-market time rather than by workplace norms or workplace externalities. Building on a simple time use model, we provide estimates for the impact of an increase in the amount of leisure undertaken by a group of workers on the demand for leisure of workers living in other households.

There are five distinct periods of school holidays in France: ten days at the end of October, two weeks at the end of December (Christmas), two weeks as winter break (typically in February), two weeks as spring break (April) and a long summer break. The dates of the summer break, the Christmas break and the October breaks are the same for all public schools all over the country, but not the dates of the winter and spring breaks. Specifically, the country is divided into three education regions and the dates of these two school breaks are shifted by one week across regions. Furthermore the order in which regions go into holidays is permutated every year according to a deterministic rule. In this set up, for any education region and in any given week of February or April, we observe a mechanical alternation of years where the week under consideration falls within school holidays and years where it falls outside school holidays. These continual shifts across regions and over years provide a unique tool for assessing how exogenous changes in the timing of work and leisure activities of individuals living with school-age children affect those of other individuals, either in the same region or in more distant ones.

French workers are entitled to a legal minimum of five weeks of paid leave per year during which they are granted the same wage as when they work. The dates of paid leave can be imposed by employers for the summer period only (May-October), but not for the 
spring and winter periods on which we focus. In this context, employees who live with school-age children have obvious incentives to adapt the dates of their spring and winter paid leave from one year to the other so as to be off during school holidays. Our basic research question is whether this induces other individuals to modify the timing of their own work and leisure activities. In particular, we ask whether employees without children tend to modify the date of their own paid leave so as to be off at the same time as employees with children. We also ask whether retired workers and unemployed workers modify the timing of their holidays so as to synchronize with the rest of the population.

From a theoretical viewpoint, it is not clear whether a change in the distribution of work and leisure activities over time for a specific group of individuals should generate parallel changes for other individuals. On the one hand, there is evidence that time spent with others is on average associated with higher levels of instant satisfaction than time spent alone (Kahneman et al. 2004, Helliwell and Putman, 2005, Sullivan, 1996). There is also a large psychological and medical literature showing the adverse effects of social isolation on mental health (see e.g. House, Landis and Umberson, 1988, Cacioppo et al., 2011). On the other hand, work and leisure synchronization is associated with infrastructure congestion as well as much higher travelling and accommodation costs. Overall, taking own holidays at the same time as our fellow citizens is associated with both negative (market-induced) interactions and positive (non-market) interactions, so that the net value of synchronization is ambiguous.

Building on the recent French Labour Force Surveys (LFS), we first confirm the existence of very significant first-stage effects of school holidays on the demand for nonmarket time of employees with school-age children: for any given week of February or April, the proportion taking a week off is on average two and a half times larger in regions and 
years when the week under consideration happens to fall within a school break (from 8 to 25 percentage points). During school holidays, parents are faced with an obvious childcare issue and taking paid leave is the simplest and cheapest way to solve the problem. But when looking at workers without children, we also detect very significant effects of school holidays. For any given week of February or April, the proportion taking a week off is about $50 \%$ higher in regions and years when the week under consideration happens to fall within a school break (from 10 to 15 percentage points). From one year to the other, many employees without children adapt the dates of their paid leave so as to be off at the same time as other workers, in spite of the negative market-induced interactions arising from synchronization.

When we further focus on the sample of workers who do not live and work in the same education region, we find that changes in the timing of paid leave are mostly driven by changes in the dates of school breaks in the region of residence, not by those in the region of work. The response of workers without children to changes in the dates of school breaks are not driven by employers, nor by workplace externalities, but mostly by externalities in nonmarket time in the region of residence.

Using the French Time Use surveys, we further show that school holidays induce workers without children to spend more time outside the workplace with others, but not more time taking care of (or interacting with) children. The main effect of school holidays is to induce employees without children to enjoy more recreational and leisure time with other adults, not to spend more time with related school-age children whose parents keep working. The demand for synchronization of employees without children is mostly driven by leisure time being more fulfilling when spent with other adults, not by child care issue. 
Building on a survey on vacation trips conducted by the French statistical office, we also find that school holidays induce an increase in both holidays taken at home and in holidays taken away from home, for both workers with and without children. The effect on holiday trips is stronger for high-income earners and encompasses a significant increase in all types of trips, including a $60 \%$ increase in the number of holiday rentals. School breaks are associated with an increase in all forms of holidays, even those which involve the highest increase in travelling and accommodation costs.

These effects on holiday trips extend to retired workers. For any given week of February or April, the proportion of retired workers who go away on vacation is about $40 \%$ to $60 \%$ higher in education regions where the week under consideration happens to fall within the school break. These effects are significant for trips motivated by the desire to spend time with relatives and friends, but also for non-family trips. Also, these effects are even more significant for retirees with higher income level - namely for those who are likely to be the least affected by negative market-induced interactions. Overall, we get clear evidence that retired workers seek to synchronize the time they spend at home and the time they spend away on holidays with the work and leisure periods of employed workers, in spite of the costs involved. We show that similar conclusions hold for unemployed workers, especially the more educated ones.

Finally, under the assumption that school holidays affect the time use decisions of workers without children only through their effects on the time use decisions of other workers in the same region, we provide an instrumental variable (IV) estimate of the cross effect of the amount of non-market time enjoyed by workers with children on the amount of non-market time enjoyed by workers without children living either in the same region or in a different one. Our IV estimates suggest that a 10 percentage points increase in the 
proportion of individuals taking a week off among parents living in a region causes a +3.0 percentage point increase in the proportion of individuals taking a week off among people without children living in the same region and $a+1.3$ percentage points increase among those living in other regions. Such positive cross effects are all the more striking as school holidays are associated with significant increases in travel and accommodation costs. We conducted specific surveys on prices which show that the costs of rail travel across large French cities becomes on average $+40 \%$ more costly when the departing city is on school holidays. Similarly, we find that holiday rentals become on average $+30 \%$ more expensive during school holiday periods. Such market-induced interactions are obviously not negligible, but our basic findings suggest that they are far from strong enough to offset the effect of complementarities in non-market time across workers.

Many studies have documented that individuals living in different households, but endowed with similar characteristics (or living in close proximity) tend to make similar labour supply decisions ${ }^{1}$. However, there is only very limited evidence on whether these similarities involve an actual synchronization of work and leisure activities as well as on whether they reflect actual externalities in time use or unobserved "correlated" effects (Manski, 1993). The study which is maybe the closest in spirit to ours is Hamermesh, Myers and Pocock (2008) who provide evidence that US citizens living in one of the few areas (such as Arizona) that do not switch to daylight saving time during the summer tend nonetheless to adjust the timing of their daily activities from one season to the other, so as to synchronize more closely with the rest of the country. In a related contribution, Jenkins and Osberg (2005) show that, across British regions, the proportion of persons of a given age group that engage

\footnotetext{
${ }^{1}$ See e.g. Woittiez and Kapteyn (1998), Aronsson and Palme (1998), Weinberg et al. (2004), Grodner and Kniesner (2006), Maurin and Moschion (2009). There exists also a long strand of literature on leisure complementarities within the household (see e.g. Hamermesh, 2002, Hallberg, 2003, Gelber, 2014, Goux, Maurin and Petrongolo 2014).
} 
in an associational activity is positively correlated with the proportion of persons in other age groups that also engage in that activity.

Our contribution to this literature is twofold. Because we are able to build on year-toyear quasi-experimental variations in the timing of school holidays, we can provide evidence on externalities in time use that cannot be confounded by any unobserved seasonal or "correlated" effects. Second, because we also observe exogenous variation in holiday regulations across regions, we are able to separately identify the effects of both withinregion and cross-region externalities. In particular, we can explore the relative importance of residential externalities (i.e., across people living in the same place) and workplace externalities (i.e., across people working in the same place). By providing evidence on crosshouseholds' externalities in leisure, our paper also contributes to the long standing debate on the role of unions and labour market regulations. As Alesina et al. (2005) note, one key issue is whether working time regulations have to be understood as a problematic departure from perfect competition or as a way to progress towards more desirable social equilibria, with fewer hours worked but higher coordination of leisure time across individuals. To the best of our knowledge, our work is one of the very first to provide quasi-experimental evidence on the demand for coordination from individuals living in different households in the same country.

The paper is organized as follows. Sections II and III describe the French regulations and the data used. Section IV provides graphical evidence on how employees adapt the timing of their paid leave to changes in the timing of school breaks. Sections $V$ and $V I$ develop an in-depth regression analysis of the effects of school breaks on the time use decisions of employees as well as on those of retired workers. Using public holidays as a source of variation in the effect of school breaks, Section VII provides additional evidence on 
the dose-response relationships between the demand for leisure of employees without children and those of employees with school-age children. Section VIII explores the price effects of an increase in the overall number of holiday makers. Finally, Section IX builds on a simple time use model to provide an instrumental variable estimate of a parameter capturing employees' taste for synchronization.

\section{Institutional Context}

\section{A. School Holidays}

In France, the school year begins in September. There are ten days of school break at the end of October (All Saints), two weeks at the end of December (Christmas), two weeks as winter break (February), two weeks as spring break (April) and two months as summer break (July-August). The dates of these breaks are the same for all public schools all over the country, except for the winter break and the spring break. Specifically, the country is divided into three education regions ( $A, B$ and $C$, designed so as to split the population evenly) and holidays dates are shifted by one week across regions. Furthermore the order in which education regions go into holidays changes every year according to a deterministic rule: if on year $t$ the first region is $A$ (for weeks $n$ and $n+1$ ), the second region $B$ (weeks $n+1$ and $n+2$ ) and the third region $C$ (weeks $n+2$ and $n+3$ ), then on year $t+1$, the order will be $C, A, B$, whereas on year $t+2$ it will be $B, C, A$ (see Figure 1 ). In addition, the starting week for the first region may itself be shifted by one week from one year to another. Specifically, the first winter break starts either on week 6 or on week 7 whereas the first spring break starts either 
on week 14 or week $15^{2}$. The exact dates of the different school breaks in the different education regions are set several years in advance.

In this set up, for any region of residence $z(z=A, B$ or $C)$ and any given week $w$, there are four possible cases, and namely cases where $z$ only is on school holidays during $w$, cases where both $z$ and another region $-z$ are on school holidays, cases where one or two other regions only are on school holidays and cases where no region is on school holidays. For weeks 6 to 10 (winter period) and weeks 14 to 18 (spring period), the regulation entails mechanical alternations of these different cases $^{3}$. These continual permutations provide a unique instrument for separate identification of seasonal effects and school holidays' effects on workers' behavior. Historically, the tourism industry obtained the introduction of this mechanism in 1964 . The idea was to increase the number of weeks of potentially maximum attendance at ski resorts, so as to minimize the risk that a single week of bad weather could threaten the entire winter sport season.

\section{B. Paid Leave}

French labour laws stipulate that employees are entitled with a minimum of five weeks of paid leave per year. The minimum requirement for paid vacation in France is actually similar to those observed in many other developed countries (such as Germany or the UK), but much more generous than in the US, which is the only rich country where employers are not required to provide paid leave (see Ray, Sanes and Schmitt, 2013).

\footnotetext{
${ }^{2}$ Over the period 2003 to 2011, winter break in the first region starts on average 5.5 weeks after the beginning of the calendar year. It corresponds on average to February the $8^{\text {th }}$, but (because school breaks do not start in the middle of a week) the actual starting date lies between February 4 and February 12 (five times before February $8^{\text {th }}$ on week 6 and four times after February $8^{\text {th }}$, on week 7).

${ }^{3}$ For example, for weeks $6,10,14$ or 18 , we observe for each region $z$ an alternation of years where $z$ only is on holidays, years where another region $-z$ only is on holidays and years where no region is on holidays. The mapping between the different weeks and the different types of alternations is given in Appendix Table A1.
} 
Each year, employees earn 1/12 of their annual right each month. They have to take the weeks of paid leave they earn during year $t$ before the end of year $t+1$. The law specifies that a minimum of 2 weeks have necessarily to be taken during the summer period ${ }^{4}$ (MayOctober) and that, conversely, a minimum of 1 week can be taken either within or outside the summer period depending on employees' needs. With respect to timing, the law stipulates that the exact dates of paid leave can be imposed by employers only for weeks taken during the summer period (May-October), but not for weeks taken outside the summer period (November-April). Given our focus on winter and spring breaks (i.e., outside the summer period), this aspect of the regulation is important: an increase in the proportion of workers taking a paid leave during winter or spring breaks rather than during the other weeks of the non-summer period cannot be interpreted as reflecting constraints imposed by employers. Before 1982, workers were entitled to four weeks of paid leave and employers could require workers to take all of them during summer. A fifth week (so called cinquième semaine) was granted to employees in 1982 by the newly elected socialist government, which also introduced the possibility for workers to take this additional week of paid leave whenever they needed to.

In this context, the only possible influence of employers is to limit the ability of nonparents to take vacation leave during school breaks, at the same time as parents. In case too many employees want to take a paid leave at the same time, employers are indeed allowed to ask some of them to change the dates of their leave and the law requires that priority should be given to those with children. Among workers with similar family responsibilities, priority should be given to the more senior workers.

\footnotetext{
${ }^{4}$ Historically, by imposing a minimum of weeks of paid leave during summer, the legislation aimed at guaranteeing all workers a minimum amount of vacation during the "good" season.
} 
In a number of firms, employees are also entitled to additional weeks of paid leave, on top of the legal minimum of five weeks. This is especially the case in public sector organizations. According to the 2001 complement of the LFS, about 50\% of public sector employees (and $20 \%$ of private sector employees) do benefit from 6 weeks of paid leave or more. According to the same survey, the vast majority of these workers are allowed to take these additional weeks of paid leave whenever they want outside the summer period.

Finally, it should be emphasized that, during a paid leave, employees are granted the same wages as when they work. They cannot carry out paid work during periods of paid leave. Also, the right to annual paid leave cannot be given up in exchange for monetary compensation. There is no income effect associated with the timing of annual leave.

\section{Data}

\section{A. Labour Force Surveys}

We first use data from the French Labour Force Surveys (LFS), conducted by the French National statistical office (INSEE) between 2003 and 2011. The LFS is conducted each quarter over a representative sample of about 37000 households. The sample was increased in the course of 2009 to reach about 55,000 households per quarter in 2010 and 2011. Observations are uniformly distributed over the weeks of the quarters ${ }^{5}$. Our analysis is based on the sub-sample of observations between week 2 and week 25 of the year. This set of weeks encompasses winter and spring school breaks, but excludes all the other school breaks, and namely all those that are not shifted across regions.

\footnotetext{
${ }^{5}$ For individuals in the sampling frame that have to be interviewed about week $w$, the interview can take place within two weeks and two days from $w$ so that appointments can be made even when $w$ falls within (or just before) a period where respondents take a week off and go away on vacation.
} 
For each household member aged 15 or above, the survey provides information on the place of residence, the place of work, age, marital status, level of education and employment status. For employed individuals, we have information on occupation, industry, private/public sector, seniority level as well as on the actual weekly hours worked. Our main sample consists of wage-earners who are not teachers and whose spouse, if any, is not a teacher. We also exclude individuals with two months (or less) of seniority since they are not yet entitled to a full week of paid leave. We focus on workers who live in households where there is either no children $(N=184,671)$ or at least one school age child, i.e. aged between 6 to 17 years old $(N=168,620)$. Appendix Table $A 2$ confirms that the number of observations per week as well as the basic demographic characteristics of respondents are balanced across school holidays weeks and non school holidays weeks.

In Appendix Table A3, we provide additional information on the subsample of workers who do not work and live in the same education region. In the next section, we build on this subsample of cross-region commuters to explore the relative importance of interactions within and outside the workplace. As it turns out, a majority of these commuters work in large urban agglomerations but live in one of the less urban local districts (departments) that surround these agglomerations. For example, about $50 \%$ of commuters work in the Parisian region (education region $A$ ) but live in one of the districts surrounding the Parisian region (typically in education region $B$ ). The key question will be whether they are more responsive to school holidays in their region of residence or to school holidays in their region of work, which is also the region where most of their co-workers live ${ }^{6}$.

\footnotetext{
${ }^{6}$ The LFS provides the employer's identification number for over $80 \%$ of respondents. For about half of them, one co-worker happens to be a LFS respondent too. Building on this information, we checked that about $80 \%$ of commuters' co-workers are actually non-commuters.
} 


\section{B. Time Use Surveys}

We also use the two last Time Use Surveys (TUS) conducted by the statistical office, in 1998 and 2010. The 1998 (2010) survey was conducted on a representative sample of about 12000 households (10 000 households). In 1998, the survey provides information on the time use decisions of all the household's members whereas in 2010 it provides information on one (randomly chosen) household's member and her spouse (if any).

Each respondent describes how she spends her time during a given random day, by interval of time of ten minutes. The survey provides information on the amount of time spent working, sleeping, eating, watching TV, home working, travelling, spending time with children ${ }^{7}$, practicing sport etc. The detailed classification of daily activities includes about 140 items. In addition, TUS collects information about whether activities are undertaken alone or with other people. The surveys also include basic characteristics of respondents, such as gender, age, household composition and employment status. The survey consists in several waves of interviewing which are designed so as to obtain a distribution of observations over the days of the year that is as close as possible to uniform. Each observation involves two face-to-face interviews, one just before and one just after the day that is described by the respondent.

Our main TUS sample consists of wage earners who are not teachers and who spouse, if any, is not a teacher. We focus again on observations that correspond to weeks 2 to 25 and we exclude those that correspond to weekends. Also we focus on either individuals living in households without children $(N=1,873)$ or individuals living in household with at least one

\footnotetext{
${ }^{7}$ The most detailed classification includes several elementary activities related to children. Specifically, it distinguishes "playing with children" or "educating children" from "providing care to children" or "driving children". It also indicates whether these activities are undertaken with children living in another household or with children living in other household. For the sake of simplicity, we built one single activity ("time spent with children") from all these elementary ones. As discussed below, workers without children in their households spent actually very little time in these different activities, both during and outside school holidays.
} 
school age child (i.e. aged 6 to 17, N=1,640). Appendix Table A4 confirms that the number of observations per week as well as the basic demographic characteristics of respondents are balanced across school holidays weeks and non school holidays weeks.

\section{Survey on Vacation Trips}

Finally, we used the survey on Vacation Trips, conducted in October 2004 by the French statistical office over a representative sample of about 6,000 households. For each household member, the survey provides information on basic demographic characteristics, employment status as well as on vacation trips taken between October 2003 and September 2004. For each trip lasting four days or more, respondents are asked to provide the exact dates of the trip, its primary motivation (as reported by the respondent), the type of accommodation they were staying in (holiday home, rental, home of friends or relatives) as well as which persons of the household they were with. We built a database indicating for each respondent and each week between week 2 and week 25 whether a (four days or more) vacation trip was taken and the basic characteristics of this trip (motivation, accommodation...). We exclude individuals who are working in the National Education or whose spouse is working the National Education. This database provides weekly information on vacation trips for 3,150 non-teacher employees (1,679 with a child aged 6-17 and 1,471 do not live with children), 257 unemployed workers, 2,387 retired workers.

\section{School Holidays and Weeks Off: Graphical Evidence}

Before moving on to the econometric analysis, we provide a simple graphical analysis of the direct and indirect effects of school holidays on workers' demand for non-market time. To start with, Figure 2 focuses on workers with school age children and plots the 
proportion taking a week off (i.e. number of weekly hours worked=0) for each week $w$ in [2;25]. For $w$ in $[6 ; 10]$ or $w$ in $[14 ; 18]$, the top line refers to observations made when $w$ actually falls within school holidays in the region of residence whereas the bottom line refers to observations made when $w$ falls outside school holidays in the region of residence. For these two subsets of weeks, the gap between the two lines provide direct evidence on the average effect of school holidays in the region of residence on the proportion of employees taking a week off. As it turns out, the Figure reveals that the proportion of employees with school-age children who do not work is about three times higher when these specific weeks fall within school holidays than when they fall outside school holidays ( $24 \%$ versus $8 \%$ ). This finding confirms that school holidays in a region have a very strong impact on the demand for non-market time of employees with school age children living in this region.

Figure 3 replicates this graphical analysis on the sample of workers without children. It reveals very similar variations in their propensity to take a week off. The proportion who do not work during weeks 6 to 10 (or 14 to 18 ) is actually about 5 percentage points higher when these weeks fall within school holidays in the region of residence (top line) than when they fall outside school holidays in the region of residence (bottom line). This result is clearly consistent with the assumption that, from one year to the other, employees without children tend to adapt the timing of their weeks of paid leave so as to be off at the same time as employees with children living in the same region.

\section{School Holidays and Weeks Off: Regression Analysis}

The graphical evidence presented in the previous section suggests that employees without children seek to synchronize their work and leisure activities with those of other 
individuals living in the same region. In this section, we develop a simple regression analysis to test the robustness of this finding as well as to look at whether these positive interactions between employees living in the same region get amplified by interactions across employees living in different regions. We also provide a separate analysis of workers who do not live and work in the same region, so as to analyse the relative importance of interactions in the workplace and interactions outside the workplace.

\section{A. School Holidays and the Probability to Take a Week Off}

For worker $i$ living in region $z$ in year $t$, we denote $Y_{\text {iwzt }}$ a variable indicating that $i$ did not work during the $w$-th week of the year $(w=2, \ldots, 25)$ and our basic regression model is,

(1) $\quad Y_{i w z t}=\alpha S_{w z t}+\beta S_{w-z t}+X_{i w z t} \theta+\varepsilon_{i w z t}$,

where $S_{\text {wzt }}$ is a dummy indicating school holidays in region $z$ during week $s$ and year $t$, $S_{\mathrm{w}-\mathrm{zt}}$ a dummy indicating school holidays during the same year and the same week in at least one other region. The $X_{\text {iwzt }}$ variable represents a set of controls which includes a full set of week fixed effects, region fixed effects and year fixed effects. The $\varepsilon_{\text {iwzt }}$ random error is assumed exogenous to the timing of school holidays. In this set-up, the key parameter is $\alpha$, which measures the effect of school holidays in region of residence on the probability to take a week off. Parameter $\beta$ represents the effects of interactions across regions, and namely the effect of school holidays outside the region of residence on the probability to take a week off in this region. Parameters $\alpha$ and $\beta$ are identified through the arbitrary changes in the time schedule of school holidays over time and across regions described in section II.

The two first columns of Table 1 show the results of model (1) when we focus on workers with school age children, and namely with at least one child aged 6 to 17. They confirm that these workers are much more likely to take a week off during school holidays 
(+18.6 percent points, which corresponds to a tripling of this proportion). By contrast, there is no evidence of significant cross-region effects for these workers: the probability that workers with school-age children take a week off in a given region is not impacted by school holidays in other regions. This result confirms that most parents have only little leeway to take a vacation leave outside periods of school holiday in their region of residence. The second column shows that these estimates are robust to the introduction of a full set of additional controls for education, gender, age, industry, private sector and part time status, confirming that the timing of school holidays is completely unrelated to the distribution of workers' characteristics across regions and over time ${ }^{8}$.

The two last columns of Table 1 replicate this regression analysis for workers without children. They show that the probability of their not working during a given week is about +5.4 percentage points higher when this week falls during school holidays, which correspond to an about $+50 \%$ increase in the proportion taking a week off during school holidays. They also reveal that individuals without children tend to take slightly more weeks off when other regions are on school holidays than when no other region is on school holidays, but that this cross-region interaction (+1.4 percentage points) is much weaker than the within-region one. Finally, the last column of Table 1 confirms that these different school holidays effects are robust to the introduction of controls for education, gender, age, industry, private sector and part time status ${ }^{9}$.

\footnotetext{
${ }^{8}$ Results are also unchanged when we further restrict the sample to the subsets of weeks 6 to 10 and 14 to 18 . As discussed above, identification in model (1) comes from annual and regional variation in hours worked for these specific weeks.

${ }^{9}$ During the 2003-2011 period, the annual permutations of the order in which the three education regions $A, B$ and $C$ go on holidays define three basic three-year cycles $(2003-2005,2006-2008,2009-2011)$ and we have also checked that the replication of our regression analysis separately on these three sub-periods provide estimates of the school holidays effects that are very stable over time and similar to those obtained on the full 2003-2011 sample. We do not detect any trends in our estimated school holidays' effects.
} 
In Appendix Table A5, we show the results of replicating the same regressions using the weekly number of hours worked $(H)$ as dependent variable. These regressions show that the increase in weeks off during school holidays translates into a reduction in weekly hours worked of about -7.5 hours for employees with children and -2.2 hours for employees without children. Appendix Tables A6 and A7 also show the results of replicating the basic regression analysis for various demographic subgroups of workers without children (defined by gender, age, family composition) as well as for different industries and seniority groups. Generally speaking, these investigations confirm that school holidays' effects on weeks off are significant for all types of workers without children, regardless of gender, age, family type, seniority or industry. Effects tend to be even more significant in public sector industries, and namely in industries where a large fraction of workers are entitled to more than five weeks of annual paid leave and find themselves less constrained about the number of weeks of paid leave they can take during the non-summer period.

\section{B. Interactions in the Workplace vs Interactions Outside the Workplace}

Our basic regression results confirm that workers without children tend to adapt their dates of paid leave from one year to the other so as to be off at the same time as workers with children living in their region. Such a demand for synchronization may be driven by non-market time being more pleasurable when enjoyed at the same time as others. But it may also be driven by workplace externalities. For example, working time may become more painful when more co-workers are absent. More in general, workplace norms may be such that people find it difficult to be on holidays when colleagues are at work.

To explore the relative importance of workplace and non-workplace interactions, we replicated our basic regression analysis on the subsample of workers who do not live and work in the same education region $A, B$ or $C$. For these cross-region commuters, it is possible 
to separately identify the effect of school holidays in the education region where they live, the effect of school holidays in the education region where they work as well as the effect of school holidays in the education region where they do not live nor work. Assuming that workplace pressure plays a dominant role, commuters should be mostly responsive to school breaks in the education region where they work, since it is also the region where the vast majority of their co-workers live.

As shown in Table 2, this analysis first confirms that cross-region commuters with school-age children mostly respond to school holidays in their region of residence, not to school holidays in the other regions. Specifically, school holidays in their region of residence is associated with an average increase of about +16.3 percentage points in their probability to take a week off whereas school holidays in other regions (including the region of work) have negligible effect on their probability to take a week off. These results are very similar to those obtained on the full sample and hold regardless of whether we include a full set of control variables or not. They are clearly suggestive that commuters with children are mostly responsive to school breaks that determine their children's holidays, not those that affect the demand for leisure of most of their co-workers.

Given these facts, the next question becomes whether cross-region commuters without children get affected by the same specific school breaks as commuters with schoolage children. The two last columns of Table 2 reveal that this is the case. Specifically, school holidays in the region of residence of cross-region commuters without children are associated with a significant increase of about +4.3 percentage points in their probability to take a week off whereas the effects of school holidays in their region of work or in the other 
region are much weaker and not statistically significant ${ }^{10}$. Again these regression results are similar to those obtained on the full sample and hold regardless of whether we include a full set of control variables or not. They provide us with clear evidence that commuters without children seek to synchronize their activities with people in their region of residence (be they commuters or not), not with their coworkers. Overall, our results are consistent with the assumption that workplace externalities play but a minor role in the decision to take a paid leave. They also confirm that the dates of (non summer) paid leave are not imposed by employers.

\section{School Holidays and Non-Market Activities}

As shown in the previous section, employees without children appear to find not working more enjoyable when other people do not work, and namely during school breaks. It is not clear, however, whether it is because they enjoy being on holidays at the same time as others or because they have to help others to take care of young children during school breaks. More in general, it is not clear which specific non-market activities are found more valuable when more other people are on holidays. To explore this issue and further characterize the nature of cross households' interactions, we built on the Time Use surveys (TUS) conducted by the French statistical office in 1999 and 2010 as well as on the survey on Vacation trips conducted in 2004.

\section{A-School Holidays and Daily Activities}

Focusing on the same January-June period as in the previous sections, we first used the TUS to compare workers' time use diaries collected within and outside periods of school

\footnotetext{
${ }^{10}$ We checked that the difference between the estimated effect of school holidays in the region of residence and the estimated effect of school holidays in the region of work is significant at the $5 \%$ level.
} 
holidays in the region of residence ${ }^{11}$. The top part of Table 3 first focuses on the effect of school holidays on the probability to take a day off (i.e., no market work at all during the day). It reveals that school holidays are associated with an increase in the probability of taking a day off which is about +16.0 percentage points for workers with school age children (column 1) and about +7.5 percentage points for workers without children (column 2 ). Hence, Time Use surveys provide us with evaluations of the effects of school holidays on workers' demand for non-market time that are qualitatively similar to those obtained with the Labour Force Surveys.

To take one step forward, the second part of the Table shows the effect of school holidays on the amount of time (in hours) spent in several basic types of activities : market work, sleep, meals, home work, leisure activities and time spent either taking care of or interacting with children. It first shows that the rise in the proportion of days off translates into a decline in time spent at work which is on average about $-23 \%$ for employees with children (i.e., $-1.55 / 6.82$ ) and $-8 \%$ for employees without children $(-0.61 / 7.33)$. This average decline in market time is associated with an increase in the amount of time spent sleeping, house working and, to a lesser extent, in the amount of time spent in leisure activities. As far as employees without children are concerned, we detect a significant increase in the amount of leisure time spent in front of screens (computer, TV) mitigated by a decline in the amount of leisure time spent outdoors (sport, walks, evening outgoings...). By contrast, we find no effect of school holidays on the amount of time that employees without children spent taking care of or interacting with children. Actually, employees without children spent on average very little time in activities involving interactions with children, regardless of whether we focus on periods of school holidays or not. This finding is clearly suggestive that

\footnotetext{
${ }^{11}$ This section focuses on the effect of school holidays in the region of residence. The size of the sample of the Time Use Survey is too small for us to jointly estimate the effect of school holidays in other regions.
} 
the increased demand for non-market time by employees without children during school holidays has little to do with children ${ }^{12}$. For their part, employees with children tend to spend less time with their children during school holidays. Further exploration shows that this negative impact is driven by a decline in time spent driving children to (or from) schools combined with a decline in time spent supervising homeworks.

Finally, the bottom part of the Table shows that school holidays are not associated with any significant increase in the amount of time spent alone either at work or during nonwork activities. The only change associated with school holidays is that interactions with others take place during non-work activities rather than at work, with a marginally significant decline in the amount of time spent at work with others (-.51 hours) and a parallel increase in the amount of non-work activities spent with others ${ }^{13}$ (+.66 hours). Would workers without children take their paid leave outside school holidays, the picture would likely be different, with a likely increase in loneliness both during school holidays (while at work) as well as outside school holidays (while taking vacation). By taking their paid leave at the same time as other workers (i.e., within school holidays), workers without children avoid having to spend more time alone at work within school holidays' periods as well as more time alone on vacation during non school holidays' periods.

\section{B. School Holidays and Vacation Trips}

\footnotetext{
${ }^{12}$ The Time Use Surveys also provide information on whether respondents took care of children from other households in the very month before the day of the survey. About $80 \%$ of respondents report no child care activities in the month before the survey and the diaries of these respondents also make no mention of time spent with children during the day of the survey. When we replicate our regression analysis on the subsample of these no-childcare workers, we find an effect on the probability to take a day off (+8.8 percent points) which is as significant as on the other workers without children.

${ }^{13}$ It is not possible to further explore with whom exactly they spend their time due to the very large number of missing information for this specific variable. When we replicate this regression analysis separately on singles and couples w/o children, we find that the substitution of time spent not alone in non-work activities for time spent not alone at work is even more significant for singles (and namely for workers for whom the substitution under consideration cannot be driven by additional leisure time with the spouse).
} 
Time use surveys (TUS) confirm that employees without children tend to work significantly less during school holidays. They also reveal that it is not to take care of children living in other households, but mostly to spend more recreational and leisure time in the company of others. In this section, we look at whether this increase in non-market time during school breaks corresponds to a mere increase in vacation at home or whether it also involves an increase in vacation trips and in holidays away from home ${ }^{14}$.

As discussed more in depth at the end of this paper, school holidays induce very significant increases in accommodation or transportation costs. Therefore, it may be that school holidays boost the demand for vacation time at home, but have no effect (or even an adverse effect) on the demand for vacation trips. In this scenario, the overall impact of school holidays on employees without children would encompass a positive effect on vacation at home and a negative effect on vacation trips.

To test this assumption, this section builds on the survey on vacation trips conducted by the French Statistical Office in 2004. It makes it possible to analyze the effect of school holidays on the probability to go away on holidays (as well as on trips' motivations and accommodation used) for a representative sample of households ${ }^{15}$.

Table 4 first confirms that school holidays in a region have a very significant impact on the demand for vacation trips of employees living in this region, even those that do not have school age children. Specifically, they induce an increase in the proportion of residents going away on holidays which is about +7.2 percentage points for employees with school age children and +1.8 percentage points for employees without children (which represents an increase in this proportion of about 60\%). These effects of school breaks on vacation trips

\footnotetext{
${ }^{14}$ TUS do not provide information on whether activities are undertaken at home or away from home.

${ }^{15}$ We use the same regression model as model (1). Identification comes from variation across weeks of the year in the differences in outcomes across education regions.
} 
represent about $1 / 3$ of the overall effects of school breaks on the probability to take a week off as estimated with the $\mathrm{LFS}^{16}$. School holidays in a region also induce an increase in vacation trips for employees without children living in other regions, but this cross region effect is much smaller in magnitude and not statistically significant.

With respect to trips' motivations, our regressions suggest that the effect of school holidays is as strong on non-family trips as on family ones. In terms of accommodations used, school holidays induce an increase in both holiday rentals and visits to friends/relatives. Overall, our findings confirm that school holidays are associated with an increase in all forms of leisure time, even the most costly ones.

In Appendix Table A8 (panel A) we provide additional regression results showing that school holidays' effects on vacation trips tend to be stronger for employees living in highincome households than for those in middle income or low income ones. In particular, school holidays are associated with an increase in the proportion of individuals renting an accommodation which is significant for high-income households only. The proportion of lowincome and middle-income workers renting an accommodation stays at very low level both within and outside school holidays. As discussed in the last section of the paper, school holidays are associated with strong increase in holiday rentals' prices. These price effects contribute to mitigating the effects of social interactions on the demand for vacation trips of low and middle-income earners during school holidays ${ }^{17}$.

\footnotetext{
${ }^{16}$ We checked that when we replicate the LFS analysis on the sole 2004 LFS sample we get estimates of school breaks 'effects that are very similar to those obtained with the full sample in Table 1 , and namely +19.7 percentage points for employees with children and +6.3 percentage points for employees without children.

${ }^{17}$ When we replicate our basic LFS analysis by income groups, we find that the impact of school break on the proportion of employees without children who take a week off is as large on middle and low-income groups as on the high income one. Price effects do not contribute to reducing the overall demand for holidays during school breaks, but appear simply to drive some substitution of holidays at home for holidays away from home.
} 


\section{School Holidays and Retired Workers}

We just provided evidence on the existence of leisure externalities across employed individuals living in different households. In this section, we explore whether similar externalities exist across employed individuals and retired individuals, and namely whether the time use decisions of employed individuals also affect those of retired individuals living in other households. This is an important issue: leisure externalities represent one key reason why changes in regulations for prime age workers may affect the labor supply and time use decisions of individuals at the margin of the labor force.

To investigate this issue, we replicated our analysis of vacation trips on the sample of retired workers ${ }^{18}$. This analysis first reveals that school holidays in a region have an effect on the proportion of residents going away on vacation trip which is as significant for retired workers as for employed workers without workers (see Table 5). The proportion of retired workers on vacation trips is about +1.9 percentage points higher during school breaks (compared to its average value, it corresponds to a $45 \%$ increase in this proportion).

With respect to motivations, Table 5 also reveals that these effects are driven by an increase in both family and non-family trips. A number of retired workers visit their children and relatives during school holidays, but this fact alone cannot explain the increase in nonfamily trips during school holidays ${ }^{19}$. We also checked that the effects on retired workers are not driven by those whose spouse is still employed: we find almost exactly the same effects when we further focus on retired workers whose spouse is retired (column 4).

In Appendix Table A8 (panel B), we provide additional regression results by income groups. They show that school holidays' effects on retired workers are much more significant

\footnotetext{
${ }^{18}$ In this analysis, we dropped the little fraction of retired workers who still live with children.

${ }^{19} \mathrm{We}$ also replicate our Time Use analysis on the sample of retirees. It suggests that retirees spend more time sleeping, taking walks or using computers during school breaks (and less time eating or house-working). But it does not show any variation in time spent with children.
} 
for high-income retirees (+4.7 percent points) than for middle-income $(+0.8)$ or low-income ones $(+0.2)$. Further analysis by type of accommodations suggests that the stronger effect on high-income retirees is driven by their higher ability to pay for holiday rentals as well as by their owning holiday homes ${ }^{20}$.

Overall, our results are suggestive that retired workers seek to synchronize their vacation trips with those of employees. This result may reflect either that they find it more pleasurable to be at home when employed people are not on vacation (maybe to help their children with child caring) or that they find it more pleasurable to be away on vacation at the same time as employed people (maybe to spend time with them). Such complementarities in time use decisions across retired and employed workers represent one basic channel through which policies affecting hours worked and leisure time of employees may eventually affect the welfare of retirees and the labour supply behavior of senior workers.

As shown in Appendix Table A9, we also replicated our basic regression analysis of vacation trips on the sample of unemployed workers. We found significant effects of school holidays for the more educated ones only. The low educated ones spend little time away on vacation, both within and outside periods of school holidays, presumably because many of them cannot afford to bear the costs. By contrast, the more educated unemployed workers go away on vacation significantly more often during school holidays, even when they do not have children. Building on the LFS, we also checked that school holidays are associated with lower rates of transition from unemployment to employment for the more educated workers, but not for the less educated workers (not reported). One interpretation for these externalities is that unemployed workers themselves tend to find vacation time more

\footnotetext{
${ }^{20}$ In 2010, according to the French statistical office, about $10 \%$ of French households own a holiday home, but the proportion is three times higher for high SES than for low SES occupations (i.e., $15 \%$ vs $5 \%$ ), where low SES occupations include blue collars and routine clerks and represent about $46 \%$ of the population (Kwok, 2010).
} 
pleasurable when enjoyed with others (as suggested by the literature on subjective weelbeing, see e.g. Young and Lim, 2014). Another interpretation is that job search activities become less productive during school holidays, even though it is not entirely clear why it should be more so for the more educated job seekers.

\section{School Breaks and Public Holidays}

As shown in the previous sections, employees without children spend very little time with children from other households, both within and outside school holidays. From one year to another they change their dates of paid leave so as to be on holidays during school breaks, at the same time as other employees, but it seems to have little to do with child care issues.

A way to further test the role of children is to compare the response of employees without children to school breaks that induce a relatively large number of employees with children to take a week off (and, consequently, a relatively small number of children to be on holidays while their parents keep working) with their response to school breaks that induce a relatively small number of employees with children to take a week off (and, consequently, a relatively large number of children to be on holidays while their parents keep working). Assuming that employees without children are mostly responsive to the number of adults on

holidays (and not to the number of children on holidays while parents keep working), employees without children should be even more responsive to the first type of school breaks than to the second one.

To implement this test, the basic difficulty is to identify a source of exogenous variation in the impact of school breaks on parents' behavior. To address this issue, we built 
on the French regulation of public holidays. In France, there are five days of public holidays between January and June ${ }^{21}$. The key point is that their dates are set according to rules that are completely independent from the regulation of school holidays. As it turns out, they never fall within weeks of winter holidays, but often fall within weeks of spring holidays. Whenever it happens, there is a clear incentive for parents to take their paid leave during these specific weeks rather than within weeks that do not include public holidays. It amounts to obtaining an additional day of paid leave (that can be taken whenever we want) against a day of public holidays (that has necessarily to be taken on a specific day). We can expect spring breaks that include a day of public holidays to induce an even larger proportion of workers to take paid leave ${ }^{22}$.

Table 6 (columns 1 and 2) tests this assumption by replicating our basic regression analysis on the subsample of observations between week $w=13$ to 21 (spring breaks' season) with two additional independent variable, and namely a dummy indicating that $w$ includes a day of public holidays and an interaction dummy indicating that $w$ falls within school holidays and includes a day of public holidays. This interacted dummy captures the difference in effect of school breaks across weeks that include a day of public holidays and other weeks.

The regression results confirm that spring breaks induce an increase in the proportion of employees with children who take a week off which is significantly larger for weeks that include a day of public holidays than for regular weeks (+2.0 percent points, which

\footnotetext{
${ }^{21}$ Specifically, we have May Day (May, 1), Victory-in-Europe Day (May, 8) as well as three days related to Easter: Easter Monday, Ascension Thursday (38 days after Easter Monday), and Pentecost Monday (49 days after Easter Monday). Easter Monday falls between late March and late April, but the exact date changes every year according to a pre-determined ecclesiastic rule, which is completely independent from the rules that determine the alternation of school holidays across French regions.

${ }^{22}$ In the German context, Merz and Osberg (2003) provide evidence that the co-ordination of leisure activities across individuals tend to be higher in länders that have the most public holidays.
} 
corresponds to a $10 \%$ increase in the effect of school breaks). This increased effect on the proportion of parents taking a paid leave is mechanically associated with a significant decline in the effect of school breaks on the proportion of children that are on holidays while parents keep working ${ }^{23}$. Given this reality, the question is whether the same result extends to employees without children. The last columns of Table 6 look at this issue by replicating the same augmented regression analysis on the subsample employees without children. It reveals that spring breaks induce an increase in the proportion of employees without children who take a week off which is +1.6 percentage points larger for weeks that include a day of public holidays than for regular weeks, and namely an increase in the impact of school breaks which has the same order of magnitude as that observed for employees with children. These regression results are clearly consistent with the assumption that the demand for non market time of employees without children dose-responds to variations in the amount of non-market time enjoyed by other adults, not to the number of children on holidays while their parents keep working.

\section{School Holidays and the Costs of Holidays}

In theory, the effects of school holidays on the demand for leisure of individuals without children reflect the combined influence of both positive (non-market) interactions and negative (market-induced) interactions. In practice, our findings are suggestive that nonmarket social interactions play the most important role, but the extent to which they are mitigated by market-induced interactions is still an open question. This section provides

\footnotetext{
${ }^{23}$ We checked that the proportion of those where children are on holidays while both parents keep working is about 5 percent points smaller during weeks of school holidays that include a day of public holidays than during regular weeks of school holidays (which correspond to a $10 \%$ decrease in this proportion).
} 
direct evidence on these negative interactions, and namely on the increase in the cost of holidays that is induced by the increased number of vacationers during school breaks.

\section{A. School Holidays and the Prices of Train Tickets}

We first explore the effect of school holidays on the costs of train travels ${ }^{24}$. As it happens, the French National Railways Company has relatively complex pricing policies, which depend on whether we use high-speed or non high-speed trains. High-speed trains represent about half of the overall rail traffic.

If classical (non high-speed) rail travel is used, booking is not compulsory and the fare depends only on travelled distance and on whether the passenger is entitled to a fare reduction. Specifically, there exist reductions for senior passengers aged 60 or more, for young passengers aged 12 to 28 , as well as for children age 12 or less accompanied by an adult. These reduction rates tend to be much weaker during school holidays' seasons (from $50 \%$ to $25 \%$ on Saturdays for instance), but do not vary over the different weeks of school holidays' seasons, and namely do not depend on which specific education region $(A, B$ or $C)$ is actually on school holidays. They induce increases in travelling costs which likely contribute to mitigating the increase in the proportion of employees without children (as well as retirees) going away on holidays during the spring breaks' season, i.e. when either own education region or other education regions are on school holidays.

If high-speed train is used, booking is compulsory and a variable pricing strategy is used, where passengers who book earlier (or during off-peak seasons) get cheaper fares. To explore the outcome of this pricing policy, we considered several rail travels between large cities located in the different education regions $(A, B$ or $C)$ and we tested whether ticket

\footnotetext{
${ }^{24}$ According to the French Survey on Transportation conducted in 2008, train travel represents about $17 \%$ of long distance trips in France (defined as $80 \mathrm{~km}$ or more away from home). See for instance Commissariat Général au Développement Durable (2010). By contrast, in the US, train travel represents only about $1 \%$ of long distance trips (Bureau of transportation statistics, 2006).
} 
prices departing from a city were dependent on whether the city was actually on school holidays or not. Specifically, we collected ticket prices for a set of departing dates (between week 6 and 14) encompassing the 2014 winter breaks' period and for four train travels: Paris-Strasbourg, Strasbourg-Paris, Paris-Rennes and Rennes-Paris ${ }^{25}$. Paris is in region $C$ and was actually in winter holidays during weeks 8 and 9 whereas Strasbourg is in region $B$ and was on winter break during weeks 9 and 10 while Rennes is in region $A$ and was on winter break during weeks 10 and 11.

Generally speaking, these data provide very clear evidence that school holidays in region of departure has an impact on ticket prices. For example, when looking at tickets Rennes-Paris booked 1 to 4 weeks in advance, the ticket price is on average 57 euros when Rennes is not on school holidays (i.e., weeks 6-9 or 12-14), but it is 79 euros when Rennes is on school holidays (i.e., weeks 8-9). Conversely, when looking at tickets Paris-Rennes booked 1 to 4 weeks in advance, the ticket price is on average 51 euros when Paris is not on school holidays (i.e., weeks 6-7 or 10-14) but it is 72 euros when Paris is on school holidays. Hence for both Paris-Rennes and Rennes-Paris, school holidays in the region of departure are associated with an increase of about $40 \%$ in the price of train tickets. To get a more synthetic picture, we normalized ticket prices ${ }^{26}$ and computed, for each possible week of departure and each train travel, the average normalized prices for departure cities actually on school holidays and the average normalized prices for other departure cities. We obtain two series of average normalized prices which are shown in Figure 4. The Figure confirms that, for a given week of departure, tickets are about $30 \%$ to $40 \%$ more expensive in cities

\footnotetext{
${ }^{25}$ For each train travel and each possible holiday week $w$, we collected prices that correspond to departure on the morning of the last Saturday of week $w-1$ (departure hour between 9:30-12:00). Prices were collected weekly from early January to late March so as to be able to control for earlier booking effects.

${ }^{26}$ For each train travel, we set to 1 the price that corresponds to a departure on week 6 and a booking 3 weeks in advance.
} 
that are on school holidays than in other cities. Overall, high-speed trains' pricing policy induces very sharp increase in travelling costs across regions which likely contribute to mitigating the increase in the demand for holidays of employees without children and retirees when their own region of residence is on school holidays.

\section{B. School Holidays and Holiday Rentals}

With respect to accommodation costs, we tested whether school holidays have an impact on holiday rentals. Historically, the three education regions $(A, B, C)$ have been defined so as to represent a similar share of the overall population, so that the aggregate number of vacationers going to the different possible holiday places is kept as constant as possible all over the weeks of the school holidays' season. Hence we should not expect holiday rentals (and more in general, prices in region of destination) to depend a lot on which education regions are actually on school holidays and to vary a lot within school holidays' periods, except maybe across weeks that differ with respect to the number of education regions that are on holidays (two regions versus one only).

To explore this issue, we collected detailed information on prices for a random sample of about 1,000 holiday rentals from the "Gîtes de France" (GdF) network. GdF was created in 1955 and is now the largest holiday rental network in Europe with about 36,000 independent rentals (with a 5 levels of quality classification) that can be rented per week (from Saturday to Saturday) all over the year and all over the country. They represent about $70 \%$ of independent holiday rentals in France. Prices are set of the start of each calendar year. For each rental, we collected online information on location, size, quality as well as rental prices for each week, for the first six months of 2014. Data were collected in early January 2014. 
Figure 5 shows the weekly evolution of average rental prices over this 6 months' period. It first reveals that the two school holidays' periods (weeks between 8 and 11 for winter breaks and weeks between 15 and 18 for spring breaks) coincide with significant increases in rental prices. For example, rental prices are on average $+15 \%$ higher during the winter holidays' period than during the adjacent periods. A second basic finding is that these rental prices do not vary significantly across weeks within school holidays' seasons, and namely do not depend on which region is actually on school holidays. When we regress weekly rental prices on a set of rental fixed effects and asset of week fixed effects, F-tests do not reject the assumption of joint equality of the week fixed effects that correspond to either winter or spring school holidays' seasons (regressions not reported). This result holds true regardless of whether we consider the full sample of rentals or the winter-sport subsample. Hence, rental prices tend to be higher during weeks when at least one education region is on school holidays, but do not depend on which specific region is on school holidays nor on whether two education regions or one education region only are on school holidays.

Overall, we just provided evidence on two basic price effects related to school holidays. First, when any region is on school holidays, there is a significant increase in accommodation costs in potential destinations' area. This price effect affects any potential vacationer and contributes to mitigating the influence of social interactions across individuals living in either the same region or in different regions. Second, when own region of residence is on school holidays, there is also an increase in the costs of travelling from own region to holiday places. This additional price effect contributes to further mitigating the influence of social interactions across individuals living in the same region. The school breaks' effects that we estimated in the previous sections encompass the partially offsetting effects of these different market-induced interactions. 


\section{Interpretation: Cross-Household Effects on Leisure Demand}

The previous sections have highlighted the reduced-form effect of school holidays on the demand for non-market time of employees without children. In this section, we assume that this reduced-form effect reflects the (direct and indirect) influence exerted by employees with children on the time use decisions of employees without children. Under this assumption, it is possible to use school holidays as a source of identification for the cross effect of the demand for non-market time of employees with children on that of employees without children. Specifically, we focus on workers without children and assume the following model,

(2) $\quad Y_{\text {iwzt }}=\gamma_{1} \underline{Y}_{\mathrm{pwzt}}+\gamma_{2} \underline{Y}_{\mathrm{pw}-\mathrm{zt}}+X_{\mathrm{iwzt}} \theta+\varepsilon_{\mathrm{iwzt}}$

where, for each week $w$, region $z$ and year $t, Y_{\text {iwzt }}$ indicates that worker $i$ takes a week off whereas $\underline{Y}_{\text {pwzt }}$ represents the proportion of workers with children in region $z$ who take a week off on week $s$ and year $t$ while $\underline{Y}_{\mathrm{pw} \text {-zt }}$ represents the proportion of workers with children in regions $-z$ who take a week off on week $w$ and year $t$. The $X_{\text {iwzt }}$ variable represents controls which include week, year and region fixed effects. The $\varepsilon_{\text {iwzt }}$ random error is again assumed exogenous to the timing of school holidays. Model (1) used in the previous section can be interpreted as a reduced form specification of Model (2) under the assumption that school holidays affect the demand for non-market time of workers without children only insofar as they affect $\underline{Y}_{\mathrm{pwzt}}$ or $\underline{Y}_{\mathrm{pw}-\mathrm{zt}}$.

In Appendix B, we develop a simple time use model which captures the main features of the French institutions and help clarify the theoretical status of parameters $\gamma_{1}$ and $\gamma_{2}$. In this model, an increase in the aggregate number of persons taking a week off may affect 
own decision $Y_{\text {iwzt }}$ either negatively (because it induces a rise in the costs of vacation) or positively (because utility functions include a taste-for-conformity parameter, as in Brock and Durlauf, 1995), so that the sign of cross-effects $\gamma_{1}$ and $\nu_{2}$ is theoretically ambiguous.

Table 7 provides an estimation of the contextual effects $\gamma_{1}$ and $\gamma_{2}$ using a dummy variable indicating that region of residence $z$ is on school holidays as well as a variable indicating the number of other regions $-z$ on school holidays as instrumental variables. The model is estimated after averaging outcomes at the region $\times$ year $\times$ week level, and namely at the very level where contextual effects and instruments are defined. First-stage regressions confirm that school holidays in region of residence $z$ are associated with a very significant increase in the proportion of parents living in $z$ taking a paid leave whereas school holidays in other regions $-z$ are associated with a very significant increase in the proportion of parents living in $-z$ taking a paid leave. The corresponding IV estimate is about .30 for $\gamma_{1}$ and .13 for $\gamma_{2}$. Both estimates are statistically significant at standard levels. These IV results are suggestive that a 10 percentage point increase in the proportion of employees with children taking holidays in a region generates an increase of about +3.0 percentage points in the proportion of employees without children taking holidays in the region and an increase of about +1.3 percentage points in other regions.

Assuming that cross effects are homogenous (i.e., cross effects of parents on nonparents are similar to those of non-parents on parents), a value of .30 for these cross effects is consistent with a value of about 1.4 for the social multiplier $1 /(1-\alpha)$ of labour supply at the region level. This is larger than the social multiplier of about 1.1 recently estimated at the household level by Goux et al. (2014). 


\section{Conclusion}

In France, the dates of the winter and spring breaks change continuously from one year to another - as well as from one region to another - according to an exogenous deterministic rule. Building on this unique feature of French regulations, this paper investigates the effect of an increase in the amount of leisure time enjoyed by families with school age children on the demand for leisure of individuals living in other households, either in the same region or in more distant places.

We first provide evidence that many employees without children change the timing of their paid leave from one year to another so as to be off at exactly the same time as employees with school age children, and namely during school breaks. We also show that employees who do not work and live in the same education region respond mostly to changes in the dates of school breaks in the region where they live not to those in the region where they work. Cross effects on households' time use choices are very significant and appear clearly to be driven by leisure externalities, not by workplace externalities.

Building on time use data, we further show that workers without children spend very little time with children from other households, both within and outside periods of school holidays. They change their holidays' dates from one year to the other so as to be able to spend more recreational and leisure time with other adults, not to take care of school-age children from other households.

Our survey on vacation trips further reveals that school holidays do not simply lead to an increase in vacation at home. We observe an increase in all forms of holidays, even those which involve the highest increases in accommodation costs during school breaks (i.e., 
rentals). These effects on vacation trips extend to retired workers (especially those in the higher income group) as well as to unemployed workers (especially the more educated).

Finally, building on a simple time use model, we provide estimates for the cross effects of an increase in the amount of leisure enjoyed by employees with children, which suggest that a 10 percentage points increase in the proportion of individuals taking a week off among employees with children living induce a +3.0 percentage point increase in the proportion of weeks off among other employees in the same region and +1.3 percentage points increase in the proportion of weeks off among other employees in other regions. These positive externalities are all the more striking as travelling and accommodation costs increase very significantly during school breaks. We conducted specific surveys showing an increase of about $30 \%-40 \%$ in the cost of high-speed train tickets during school breaks as well as an average increase of about $15 \%-20 \%$ in the cost of holiday rentals.

Overall, our paper provides an array of evidence that leisure externalities across households are important, which has implications for most social policies. Many western countries struggle with persistently low employment rates and consider introducing more flexible regulations such as Sunday work or unrestricted overtime. The idea is to reinvigorate labour markets by increasing individuals' employment opportunities. The problem is that such reforms are also likely to affect individuals' behaviour and wellbeing indirectly, by desynchronizing work schedules and making interactions with others more difficult. The overall outcome could be a gain in overall number of hours worked, but not necessarily a gain in social welfare. 


\section{References}

Alesina Alberto, Edward L. Glaeser and Bruce Sacerdote, 2005, "Work and Leisure in the U.S. and Europe: Why So Different?", NBER Macroeconomics Annual, 20, pp. 1-100.

Aronsson Thomas and Marten Palme, 1998, "A Decade of Tax and Benefit Reforms in Sweden: Effects on Labour Supply, Welfare and Inequality", Economica, Vol. 65, n²57, pp. 39-67.

Bureau of Transportation Statistics, 2006, Long Distance Transportation Patterns: Mode Choice, BTS, Washington DC.

Brock William A. and Steven N. Durlauf, 1995, "Discrete Choice with Social Interactions I: Theory", NBER Working Papers n 5291.

Cacioppo John T., Louise C. Hawkley, Greg J. Norman and Gary G. Berntson, 2011, “Social isolation", Annals of the New York Academy of Sciences, 1231 (1), pp. 17-22.

Commissariat Général au Développement Durable, 2010, La Mobilité des Français: panorama issu de l'enquête transports et déplacements 2008 , CGDD, Paris.

Gelber Alexander M., 2014, "Taxation and the Earnings of Husbands and Wives: Evidence from Sweden," forthcoming, Review of Economics and Statistics.

Goux Dominique, Eric Maurin and Barbara Petrongolo, 2014, "Worktime Regulations and Spousal Labor Supply", American Economic Review, Vol. 104, n²1, pp; 252-76.

Grodner Andrew and Thomas J. Kniesner, 2006, "Social Interactions in Labor Supply", Journal of the European Economic Association, Vol. 4, $\mathrm{n}^{\circ}$ 6, pp. 1226-1248.

Hallberg Daniel, 2003, "Synchronous Leisure, Jointness and Household Labour Supply", Labour Economics, Vol. 10, n², pp: 185-203.

Hamermesh Daniel S., 2002, "Timing, Togetherness and Time Windfalls", Journal of Population Economics, Vol. 15, n 4, pp. 601-623. 
Hamermesh Daniel S., Caitlin Knowles Myers and Mark L. Pocock, 2008, "Cues for Timing and Coordination: Latitude, Letterman, and Longitude", Journal of Labor Economics, Vol. 26, $n^{\circ} 2$, pp. 223-246.

Helliwell John F. and Robert D. Putnam, 2005, "Social Capital and Well-being", in F.A. Huppert , N. Baylis and B. Keverne eds., The Science of Happiness, pp. 435-51. Cambridge: Cambridge University Press.

House James S., Karl R. Landis and Debra Umberson, 1988, "Social Relationships and Health", Science, New Series, Vol. 241, n 4865, pp. 540-545.

Jenkins Stephen P. and Lars Osberg, 2005, "Nobody to play with? : The implications of leisure coordination", in The economics of time use, Elsevier, Amsterdam, pp. 113-145.

Kahneman Daniel, Alan B. Krueger, David Schkade, Norbert Schwarz and Arthur Stone, 2004, "Toward National Well-Being Accounts", American Economic Review, Vol. 94, n² 2.

Kwok Patrick, 2010, "Cinq millions de ménages multipropriétaires", Observation et statistiques, $\mathrm{n}^{\circ} 49$.

Manski Charles F., 1993, "Identification of Endogenous Social Effects: The Reflection Problem", Review of Economic Studies, Vol. 60, n³, pp. 531-542.

Maurin Eric and Julie Moschion, 2009, "The Social Multiplier and Labor Market Participation of Mothers", American Economic Journal: Applied Economics, vol. 1, n 1), pp. 251-272.

Merz Joachim and Lars Osberg, 2006, "Keeping in Touch: A Benefit of Public Holidays", IZA Discussion Papers, $n^{\circ} 2089$.

Ray Rebecca, Milla Sanes and John Schmitt, 2013, "No-Vacation Nation Revisited", CEPR Research Report. 
Sullivan Oriel, 1996, "Time co-ordination, the domestic division of labour and affective relations: time use and the enjoyment of activities with couples", Sociology, Vol. 30, pp. 79-100.

Weinberg Bruce A., Patricia B. Reagan and Jeffrey J. Yankow, 2004, "Do Neighborhoods Affect Hours Worked? Evidence from Longitudinal Data", Journal of Labor Economics, vol. $\left.22, n^{\circ} 4\right)$, pp. 891-924.

Woittiez Isolde and Arie Kapteyn, 1998, "Social interactions and habit formation in a model of female labour supply", Journal of Public Economics, vol. 70, n² 2, pp. 185-205.

Young Cristobal and Chaeyoon Lim, 2014, "Time as a network good", Sociological Science, Vol. 1, pp. 10-27. 
Figure 1 - School holidays regulation in France

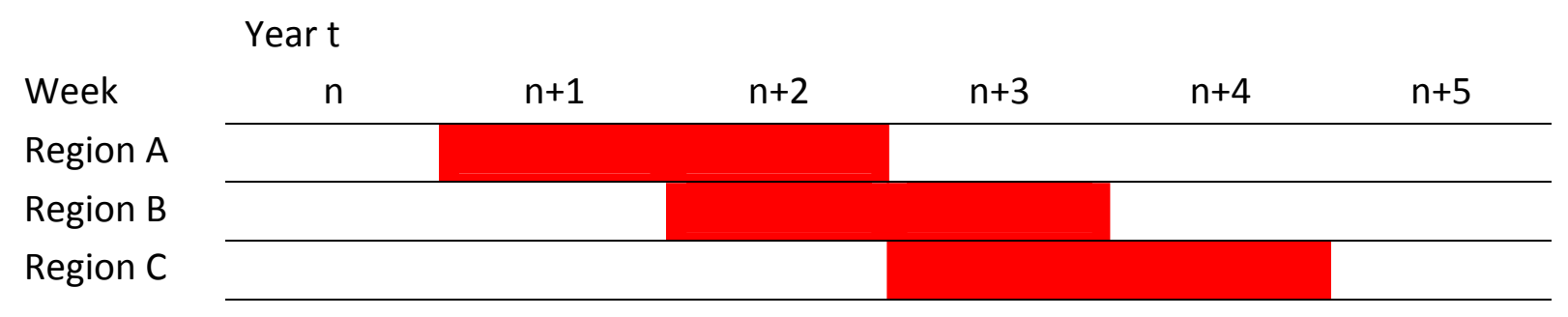

\section{Year $\mathrm{t}+1$}

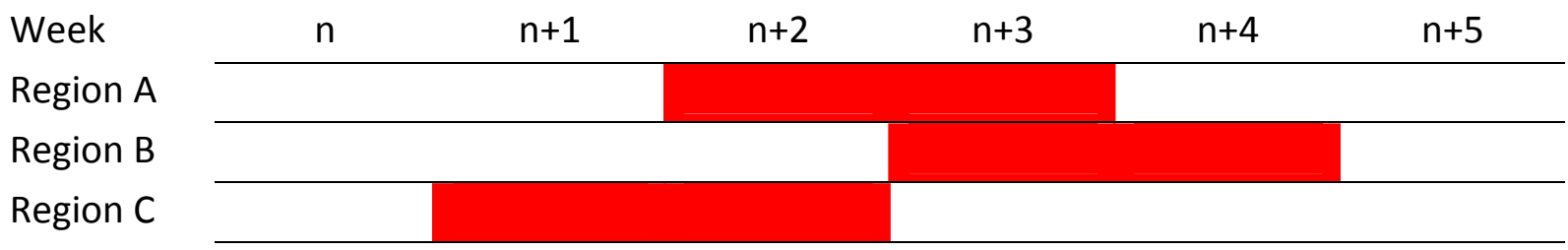

Year $\mathrm{t}+2$

\begin{tabular}{lllllll} 
Week & $n$ & $n+1$ & $n+2$ & $n+3$ & $n+4$ & $n+5$ \\
\cline { 2 - 6 } Region A & & & & \\
Region B & & & & & \\
Region C & & & & & \\
\cline { 2 - 7 }
\end{tabular}

Note: for each year and each education region $(A, B$ or $C)$, periods in red correspond to weeks of school holidays. On year $t$, Region $A$ is on holidays on weeks $n+1$ and $n+2$. On year $t+1$, it is on holidays on weeks $n+2$ and $n+3$. 
Figure 2 - School holidays and weeks off: employees with children 6-17

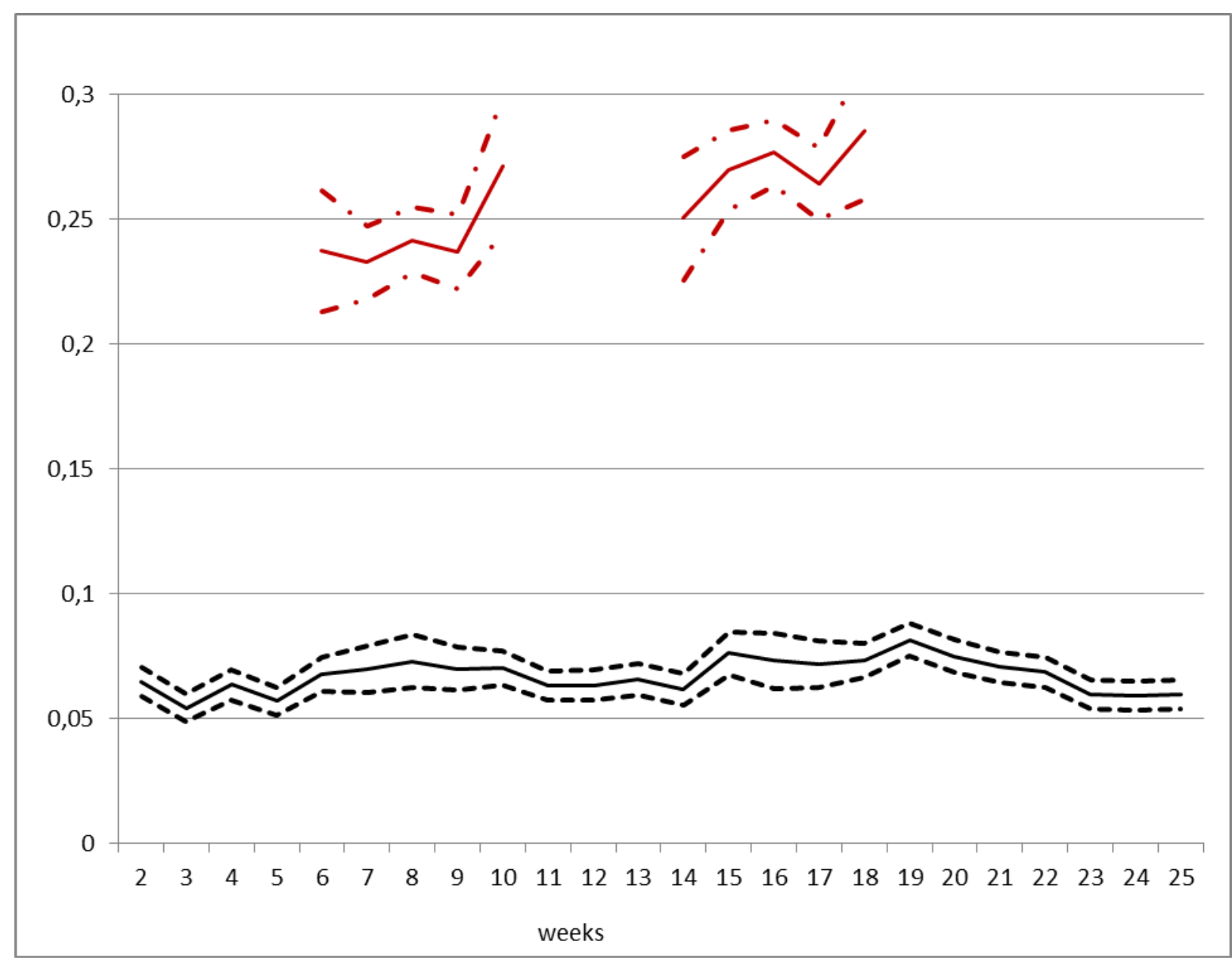

Note : For weeks $w$ in [2;25], the bottom line shows the proportion of employees with children 6-17 taking a week off when $w$ does not fall within school holidays. For weeks $w$ in $[6 ; 10]$ or in $[14 ; 18]$, the top line shows the proportion of employees with children 6-17 taking a week off when $w$ falls within school holidays. For these specific weeks, the gap between top and bottom line captures the effect of school breaks on the proportion of employees with children 6-17 taking a week off. 
Figure 3-School holidays and weeks off: employees without children

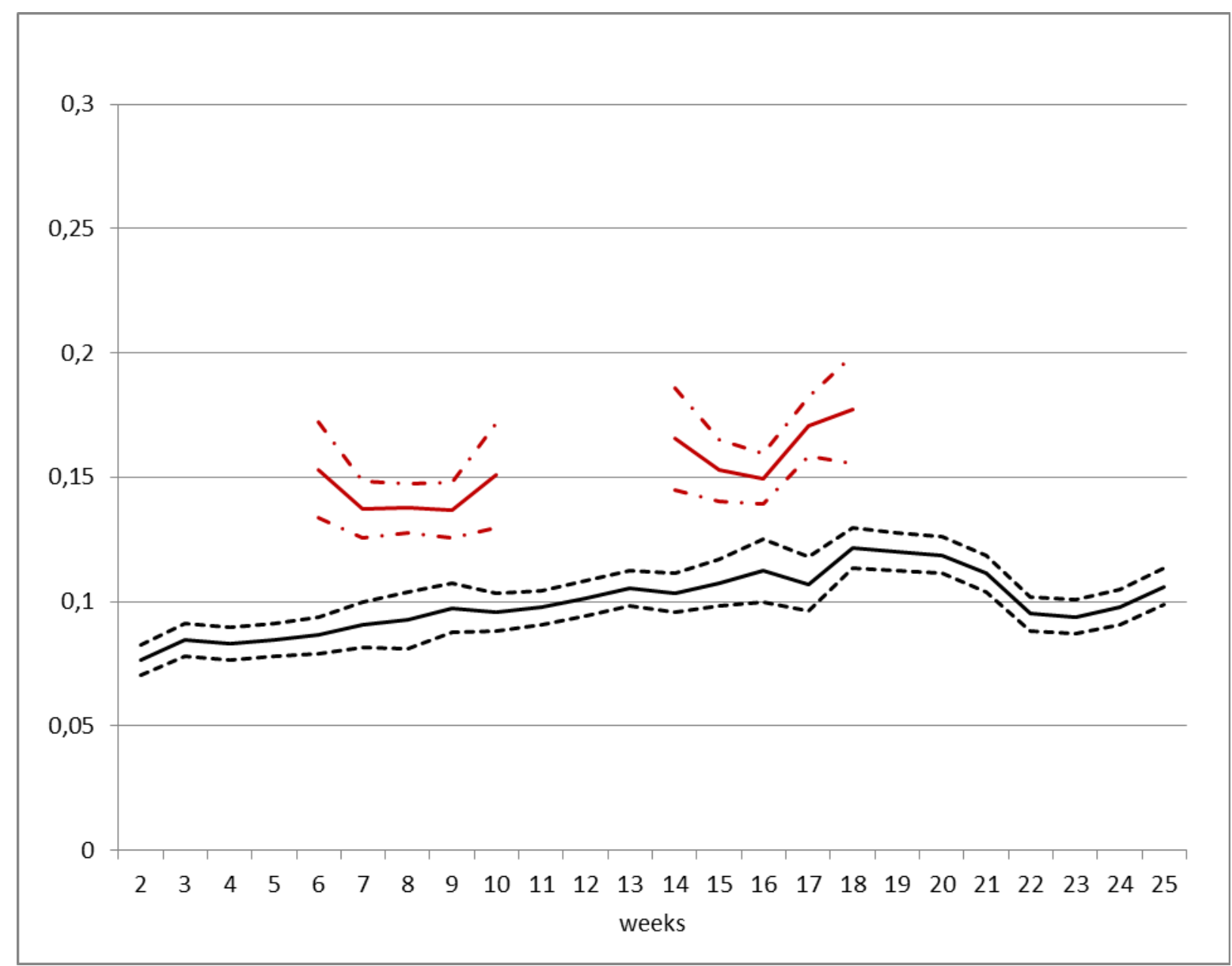

Note : For weeks $w$ in [2;25], the bottom line shows the proportion of employees without children taking a week off when $w$ does not fall within school holidays. For weeks $w$ in $[6 ; 10]$ or in $[14 ; 18]$, the top line shows the proportion of employees without children taking a week off when $w$ falls within school holidays. For these specific weeks, the gap between top and bottom line captures the effect of school breaks on the proportion of employees without children taking a week off. 
Figure 4 - School holidays and the cost of high-speed train travels (winter 2014)

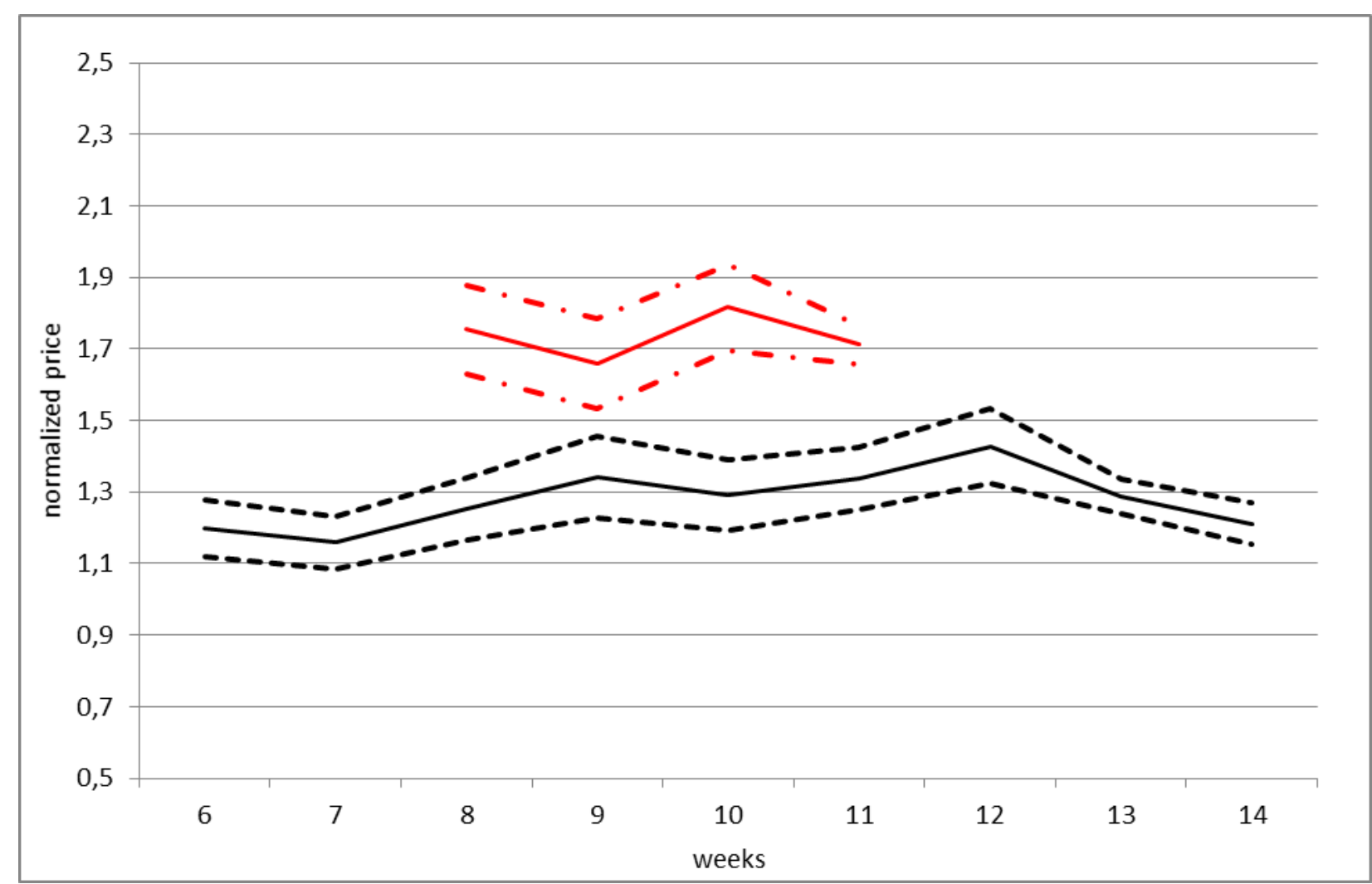

Note: The figure shows the prices of train tickets for four train travels (Paris-Rennes, Rennes-Paris, Paris-Strasbourg, Strasbourg-Paris). For weeks in $[6 ; 14]$, the bottom line shows average normalized prices when the departure city is not on school holidays, whereas the top line shows average normalized prices when the departure city is on school holidays. Prices are normalized so that their value is set to one for tickets corresponding to a departure on week 6 and a booking 3 weeks in advance. 
Figure 5 - Holiday rentals

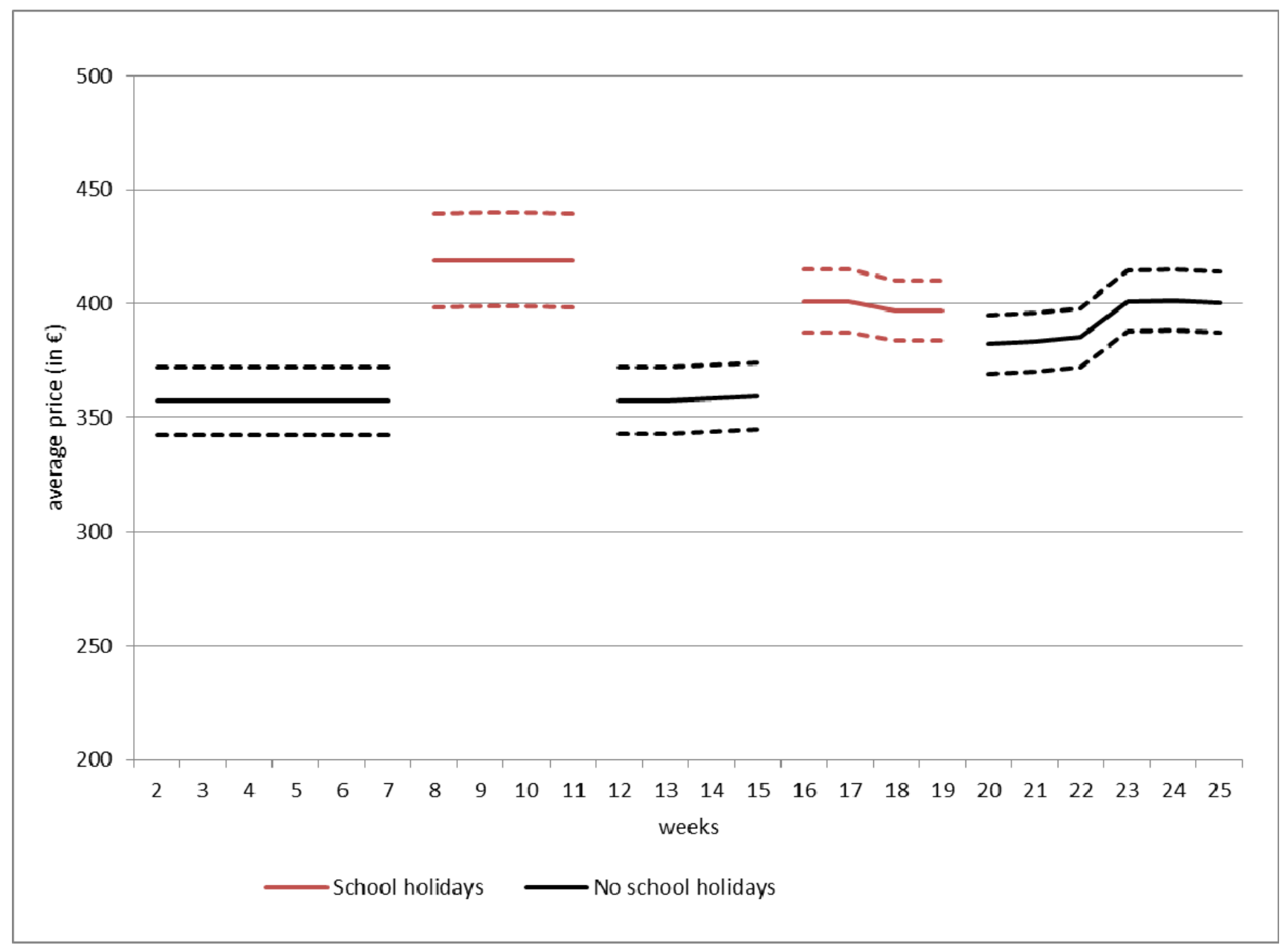

Note: For weeks in [2;25], the figure shows average rental prices for holiday rentals in the Gite de France network. 
Table 1 - School holidays and weeks off

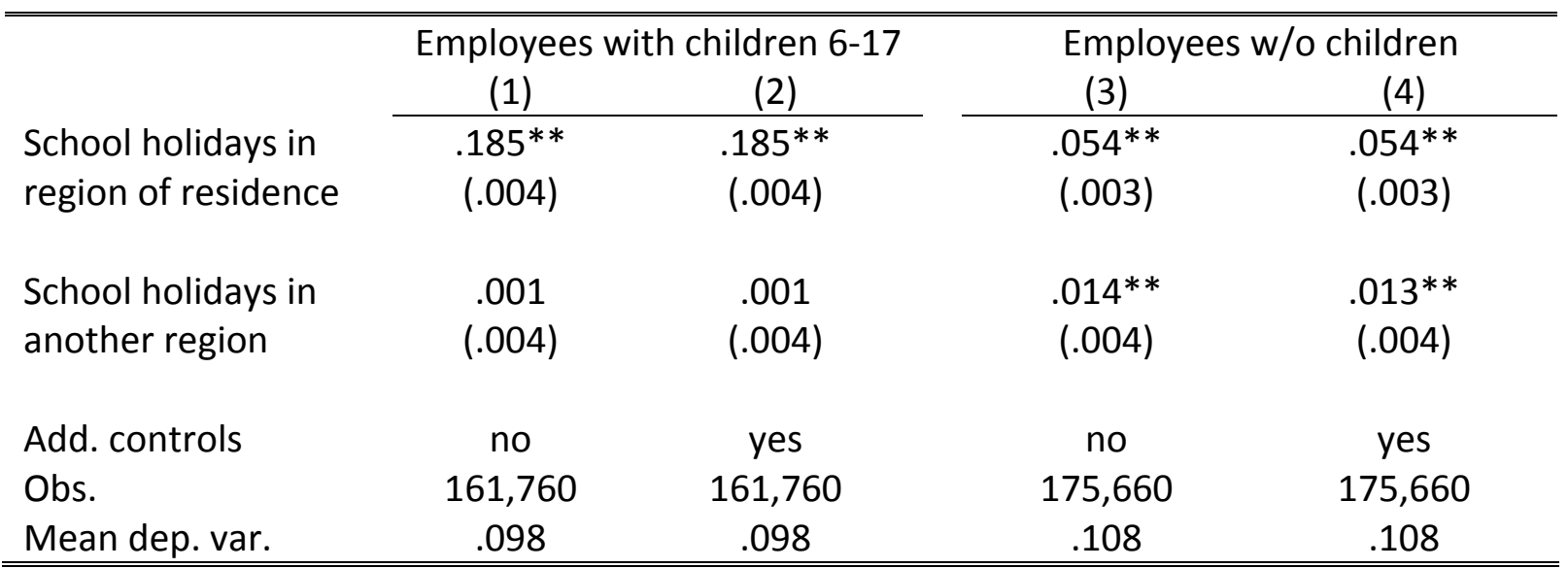

Notes: The sample includes employees observed between weeks 2 and 25, excluding those who are in the national education (or whose spouse, if any, is in the national education) as well as those with two or less months of seniority. Columns (1) and (2) refer to the subsample with children aged 6-17 whereas columns (3) and (4) refer to the subsample without children. The table shows the results from reduced-form regressions in which a dummy indicating that a worker takes a week off during week $w$, in year $t$ and region $z$ is regressed on a dummy indicating that $w$ corresponds to school holidays in $z$ and $t$, a dummy indicating that $w$ corresponds to school holidays in another region in year $t$. Control variables in columns 1 and 3 include 20 region dummies, 23 week dummies, 8 year dummies. Additional controls in columns 2 and 4 include dummies for gender, education level ( 5 dummies), private sector, part-time work, age (4 dummies) and industry (10 dummies). Standard errors clustered at the household level are reported in parentheses. Source: French LFS, 2003-2011, INSEE. 
Table 2 - School holidays and weeks off: the case of cross-region commuters

\begin{tabular}{|c|c|c|c|c|}
\hline & \multicolumn{2}{|c|}{ Employees with children 6-17 } & \multicolumn{2}{|c|}{ Employees w/o children } \\
\hline & (1) & $(2)$ & (3) & (4) \\
\hline \multirow{2}{*}{$\begin{array}{l}\text { School holidays in } \\
\text { region of residence }\end{array}$} & $.162 * *$ & $.163^{* *}$ & $.041^{* *}$ & $.043^{* *}$ \\
\hline & $(.019)$ & $(.019)$ & $(.019)$ & $(.019)$ \\
\hline \multirow{2}{*}{$\begin{array}{l}\text { School holidays in } \\
\text { region of work }\end{array}$} & .006 & .009 & -.002 & -.003 \\
\hline & $(.019)$ & $(.019)$ & $(.019)$ & $(.019)$ \\
\hline \multirow{2}{*}{$\begin{array}{l}\text { School holidays in } \\
\text { the other region }\end{array}$} & -.014 & -.012 & .011 & .012 \\
\hline & $(.019)$ & $(.019)$ & $(.019)$ & (.019) \\
\hline Add. controls & no & yes & no & yes \\
\hline Obs. & 6,537 & 6,537 & 6,476 & 6,476 \\
\hline Mean dep. var. & .104 & .104 & .121 & .121 \\
\hline
\end{tabular}

Notes: The sample includes employees observed between weeks 2 and 25 and who do not work and live in the same education region. We exclude those who are in the national education (or whose spouse, if any, is in the national education) as well as those with two or less months of seniority. Columns (1) and (2) refer to the subsample with children aged 6-17 whereas columns (3) and (4) refer to the subsample without children. The table shows the results from reduced-form regressions in which a dummy indicating that a worker living in region $z$ and working in region $z^{\prime}$ takes a week off during week $w$, in year $t$ is regressed on a dummy indicating that $w$ corresponds to school holidays in $z$ and $t$, a dummy indicating that $w$ corresponds to school holidays in $z^{\prime}$ and $t$, a dummy indicating that $w$ corresponds to school holidays in the other education region in year $t$ and a dummy indicating that $w$ includes a day of public holidays in year $t$. Control variables in columns 1 and 3 include 20 region dummies, 23 week dummies, 8 year dummies. Additional controls in columns 2 and 4 include dummies for gender, education level (5 dummies), private sector, part-time work, age (4 dummies) and industry (10 dummies). Standard errors clustered at the household level are reported in parentheses. Source: French LFS, 2003-2011, INSEE. 
Table 3 - School holidays and daily activities

\begin{tabular}{|c|c|c|c|c|}
\hline \multirow[b]{2}{*}{ - No paid work $(H=0)$} & \multicolumn{2}{|c|}{$\begin{array}{l}\text { Workers with children 6- } \\
\qquad 17(\mathrm{~N}=1,640)\end{array}$} & \multicolumn{2}{|c|}{$\begin{array}{l}\text { Workers w/o children } \\
\qquad(N=1,873)\end{array}$} \\
\hline & .205 & $+.160(.039) * *$ & .158 & $+.075(.029) * *$ \\
\hline \multicolumn{5}{|l|}{ - Daily activities } \\
\hline Paid work & 6.82 & $-1.55(.37) * *$ & 7.33 & $-.61(.31) * *$ \\
\hline Sleep & 8.03 & $+.22(.16)$ & 7.90 & $+.30(.13) * *$ \\
\hline Meal & 1.93 & $+.35(.08) * *$ & 1.92 & $+.03(.09)$ \\
\hline Home work & 2.29 & $+.65(.20) * *$ & 2.05 & $+.22(.15)$ \\
\hline Leisure & 2.84 & $+.38(.18)^{* *}$ & 3.27 & $+.06(.18)$ \\
\hline Computer & 0.16 & $+.06(.04)$ & 0.24 & $+.12(.06) * *$ \\
\hline$T V$ & 1.49 & $+.08(.13)$ & 1.59 & $+.18(.13)$ \\
\hline Sport, walks, outgoings & 0.28 & $+.08(.06)$ & 0.26 & $-.11(.07)$ \\
\hline Other leisure & 0.91 & $+.17(.13)$ & 1.18 & $-.13(.12)$ \\
\hline Children & 0.80 & $-.26(.09) * *$ & 0.06 & $+.03(.03)$ \\
\hline Other & 1.29 & $+.21(.12) *$ & 1.48 & $-.03(.12)$ \\
\hline \multicolumn{5}{|l|}{ - Alone/not alone } \\
\hline Activities alone & 6.25 & $-.75(.42) *$ & 9.16 & $-.15(.48)$ \\
\hline Work alone & 1.44 & $-.39(.24) *$ & 1.68 & $-.03(.25)$ \\
\hline Non work alone & 4.81 & $-.36(.64)$ & 7.49 & $-.13(.41)$ \\
\hline Activities not alone & 17.75 & $+.75(.42) *$ & 14.84 & $+.15(.48)$ \\
\hline Work not alone & 4.58 & $-.91(.34) * *$ & 4.80 & $-.51(.30) *$ \\
\hline Non work not alone & 13.17 & $+1.66(.44) * *$ & 10.04 & $+.66(.46)$ \\
\hline
\end{tabular}

Notes: The sample includes employees observed between weeks 2 and 25, excluding those who are in national education (or whose spouse, if any, is in national education). Columns (1) and (2) refer to the subsample with children aged 6-17 whereas columns (3) and (4) refer to the subsample without children. The top of the table shows the results from a reduced-form regression in which a dummy indicating that a worker takes a day off during week $w$, in year $t$ and region $z$ is regressed on a dummy indicating that $w$ falls in a period of school holidays in $z$ and $t$. Control variables include 20 region dummies, 23 week dummies, 8 year dummies, dummies for gender, education level ( 5 dummies), private sector, part-time work, age (7 dummies) and a dummy for part-time work unknown. For each subsample, the first column gives the average dependent variable and the second column gives the estimates effect of school holidays. The second part of the Table replicates the same regression analysis using variables describing the number of hours spent in various daily activities as dependent variables. The bottom panel replicates the same analysis using variables describing the amount of time spent alone in non-work activities (or at work) as dependent variables. Standard errors clustered at the household level are reported in parentheses. Source: French Time Use Surveys, 1999 and 2010, INSEE. 
Table 4 - School holidays and employees' vacation trips

\begin{tabular}{|c|c|c|c|c|c|c|}
\hline \multirow[t]{3}{*}{ Panel A } & \multicolumn{6}{|c|}{ Employees with children } \\
\hline & \multirow[t]{2}{*}{ All trips } & \multicolumn{2}{|c|}{ Motivations } & \multicolumn{3}{|c|}{ Accommodations } \\
\hline & & $\begin{array}{c}\text { Relatives/ } \\
\text { friends }\end{array}$ & $\begin{array}{l}\text { Non } \\
\text { family }\end{array}$ & $\begin{array}{l}\text { Holiday } \\
\text { home }\end{array}$ & Relatives/friends & $\begin{array}{c}\text { Vacation } \\
\text { rental }\end{array}$ \\
\hline & $(1)$ & $(2)$ & (3) & $(4)$ & $(5)$ & (6) \\
\hline \multirow[t]{2}{*}{ School break } & $.072 * *$ & $.035^{* *}$ & $.036 * *$ & $.009 * *$ & $.028 * *$ & $.033 * *$ \\
\hline & $(.006)$ & $(.004)$ & $(.005)$ & $(.002)$ & $(.004)$ & $(.004)$ \\
\hline School break & $.016^{* *}$ & $.013^{* *}$ & .003 & $.007 * *$ & .006 & .003 \\
\hline other region & $(.008)$ & $(.005)$ & $(.006)$ & $(.002)$ & $(.005)$ & $(.006)$ \\
\hline Obs. & 40,296 & 40,296 & 40,296 & 40,296 & 40,296 & 40,296 \\
\hline Mean dep. var. & .017 & .007 & .010 & .001 & .006 & .009 \\
\hline \multirow[t]{4}{*}{ Panel B } & \multicolumn{6}{|c|}{ Employees without children } \\
\hline & \multirow[t]{2}{*}{ All trips } & \multicolumn{2}{|c|}{ Motivations } & \multicolumn{3}{|c|}{ Accommodations } \\
\hline & & $\begin{array}{l}\text { Relatives/ } \\
\text { friends }\end{array}$ & Other & $\begin{array}{l}\text { Holiday } \\
\text { home }\end{array}$ & $\begin{array}{c}\text { Relatives } \\
\text { /friends }\end{array}$ & $\begin{array}{c}\text { Vacation } \\
\text { rental }\end{array}$ \\
\hline & $(1)$ & $(2)$ & (3) & (4) & $(5)$ & $(6)$ \\
\hline \multirow[t]{2}{*}{ School break } & $.018 * *$ & $.010 * *$ & $.009 *$ & .002 & $.010 * *$ & .006 \\
\hline & $(.005)$ & $(.003)$ & $(.004)$ & $(.002)$ & $(.003)$ & $(.004)$ \\
\hline School break & .007 & .003 & .004 & .001 & .001 & .008 \\
\hline other region & (.007) & $(.005)$ & $(.006)$ & $(.002)$ & $(.005)$ & $(.005)$ \\
\hline Obs. & 35,304 & 35,304 & 35,304 & 35,304 & 35,304 & 35,304 \\
\hline Mean dep. var. & .028 & .011 & .017 & .002 & .009 & .014 \\
\hline
\end{tabular}

Notes: The sample includes employees observed between weeks 2 and 25, excluding those who are in national education (or whose spouse, if any, is in national education). Panel A refers to the subsample with children aged 6-17 whereas panel B refers to the subsample without children. Column 1 shows the results from a reduced-form regression in which a dummy indicating that a worker goes away on a vacation trip during week $w$ in region $z$ is regressed on a dummy indicating that $w$ falls within school holidays in $z$ and a dummy indicating that $w$ falls within school holidays in another region. Control variables include week dummies and individual fixed effects. Column 2 (column 3 ) replicates this analysis using a dummy indicating that a worker goes away on a vacation trip motivated by the desire to spend time with relatives or friends (non-family motivations) as dependent variable. Column 4 uses a dummy indicating that a worker goes away on a trip to a holiday home as dependent variable, whereas column 5 uses a dummy indicating a trip to a friend's or a relative's home, whereas column 6 uses a dummy indicating a trip to a holiday rental. Standard errors clustered at the household level are reported in parentheses. Source: Vacation Trip Survey, 2004, INSEE. 
Table 5 - Shool holidays and retired workers' vacation trips

\begin{tabular}{|c|c|c|c|c|}
\hline & $\begin{array}{l}\text { Any trip } \\
\text { (1) }\end{array}$ & $\begin{array}{l}\text { Family trip } \\
\text { (2) }\end{array}$ & $\begin{array}{c}\text { Non-family trip } \\
\text { (3) }\end{array}$ & $\begin{array}{c}\text { Spouse retired too } \\
\text { (4) }\end{array}$ \\
\hline School holidays & $\begin{array}{l}.019 * * \\
(.005)\end{array}$ & $\begin{array}{l}.010^{* *} \\
(.004)\end{array}$ & $\begin{array}{l}.009 * * \\
(.003)\end{array}$ & $\begin{array}{l}.021^{* *} \\
(.008)\end{array}$ \\
\hline $\begin{array}{l}\text { School break other } \\
\text { region }\end{array}$ & $\begin{array}{l}.006 \\
(.006)\end{array}$ & $\begin{array}{l}.004 \\
(.004)\end{array}$ & $\begin{array}{l}.003 \\
(.005)\end{array}$ & $\begin{array}{l}.004 \\
(.010)\end{array}$ \\
\hline $\begin{array}{l}\text { Mean dep. var. } \\
\text { Obs. }\end{array}$ & .042 & .020 & .022 & .048 \\
\hline
\end{tabular}

Notes: The Table shows the results of replicating the same regression analysis as in Table 4 on the sample of retired workers. The sample includes observations between weeks 2 and 25 of retired workers (excluding those living with children). The last column refers to the subsample of those whose spouse (if any) is retired too. The mean of the dependent variable is given by $m$. Standard errors clustered at the household level are reported in parentheses. Source: Vacation Trip Survey, 2004, INSEE. 
Table 6 - School holidays, public holidays and weeks off

\begin{tabular}{|c|c|c|c|c|}
\hline \multirow{4}{*}{ School holidays } & \multicolumn{2}{|c|}{ Employees with children 6-17 } & \multicolumn{2}{|c|}{ Employees w/o children } \\
\hline & $(1)$ & $(2)$ & $(3)$ & (4) \\
\hline & $.189 * *$ & $.188 * *$ & $.047^{* *}$ & $.048^{* *}$ \\
\hline & $(.006)$ & $(.006)$ & $(.005)$ & $(.005)$ \\
\hline School holidays & -.001 & -.000 & $.017^{* *}$ & $.016^{* *}$ \\
\hline other regions & $(.006)$ & $(.006)$ & $(.005)$ & $(.005)$ \\
\hline Public holidays & $.011^{* *}$ & $.010 * *$ & $.027^{* *}$ & $.027^{* *}$ \\
\hline & $(.003)$ & $(.003)$ & $(.004)$ & $(.004)$ \\
\hline Public holidays $\mathrm{x}$ & $.020 * *$ & $.020 * *$ & $.016^{*}$ & $.016^{*}$ \\
\hline School holidays & $(.010)$ & $(.010)$ & $(.008)$ & $(.008)$ \\
\hline Controls & no & yes & no & Yes \\
\hline Obs. & 60,672 & 60,672 & 66,577 & 66,577 \\
\hline Mean dep. var. & .117 & .117 & .123 & .123 \\
\hline
\end{tabular}

Notes: The table shows the results of replicating the same reduced form regression as in Table 1 with two additional independent variables, and namely a dummy indicating that week $w$ includes a day of public holidays in year $t$ and a dummy indicating that $w$ includes a day of public holiday and falls within school holidays in year $t$ and region $z$. The sample is restricted to weeks 13 to 21 (spring period). Standard errors clustered at the household level are reported in parentheses. Source: French LFS, 2003-2011, INSEE. 
Table 7 - Cross effects on leisure demand at the region level: IV estimates

\begin{tabular}{|c|c|c|c|}
\hline & \multicolumn{2}{|c|}{ First stage } & \multirow{2}{*}{$\begin{array}{c}\text { IV } \\
\text { Prop. of workers w/o } \\
\text { children off } \\
\left(\underline{Y}_{\text {nwzt }}\right)\end{array}$} \\
\hline & $\begin{array}{c}\text { Prop. of workers } \\
\text { with children 6-17 } \\
\text { off }\left(\underline{Y}_{\text {pwzt }}\right)\end{array}$ & $\begin{array}{c}\text { Prop. of workers } \\
\text { with children 6-17 } \\
\text { off in other region } \\
\left(\underline{Y}_{p w-z t}\right)\end{array}$ & \\
\hline $\begin{array}{l}\text { School holidays in the } \\
\text { region }\end{array}$ & $\begin{array}{l}.190 * * \\
(.004)\end{array}$ & $\begin{array}{l}.008^{* *} \\
(.003)\end{array}$ & - \\
\hline $\begin{array}{l}\text { Number other regions on } \\
\text { school holidays }\end{array}$ & $\begin{array}{l}.006 * \\
(.003)\end{array}$ & $\begin{array}{l}.099 * * \\
(.003)\end{array}$ & - \\
\hline $\begin{array}{l}\text { Prop. of workers with } \\
\text { children } 6-17 \text { off in the } \\
\left.\text { region ( } \underline{Y}_{\text {pwzt }}\right)\end{array}$ & - & - & $\begin{array}{l}.30 * * \\
(.02)\end{array}$ \\
\hline $\begin{array}{l}\text { Prop. of workers with } \\
\text { children off in other region } \\
\left.\left(\underline{Y}_{\mathrm{pw}-\mathrm{zt}}\right)\right)\end{array}$ & - & - & $\begin{array}{l}.13^{* *} \\
(.04)\end{array}$ \\
\hline Mean dep. var. & .096 & .097 & .106 \\
\hline Obs. & 648 & 648 & 648 \\
\hline
\end{tabular}

Note: Column 3 shows the results of regressing the proportion of workers without children taking a week off in region z, week $w$ and year $t\left(\underline{Y}_{n w z t}\right)$ on the proportion of workers with children taking a week off in z, w, $t\left(\underline{Y}_{\text {pwzt }}\right)$ and the proportion of workers with children taking a week off in other regions $\left(\underline{Y}_{\mathrm{pw}-\mathrm{zt}}\right)$, using a dummy indicating school holidays in $z, w, t$ and a variable indicating the number of other regions on school holidays on $w$ and t. Columns 1 and 2 shows the results of the corresponding first stage regressions. Control variables include full set of dummies for week fixed effects, year fixed effects and region fixed effects. Source: Labour force surveys, 2003-2011, INSEE. 


\section{Appendix A}

Table A1 - Mapping between weeks and types of school holidays' alternation

\begin{tabular}{|c|c|c|c|c|c|c|c|c|c|c|c|c|c|c|c|c|c|c|}
\hline & \multirow[b]{2}{*}{$(z,-z)$} & \multirow[b]{2}{*}{4} & \multirow[b]{2}{*}{5} & \multirow[b]{2}{*}{6} & \multirow[b]{2}{*}{7} & \multirow[b]{2}{*}{8} & \multicolumn{3}{|c|}{ Week number } & \multirow[b]{2}{*}{12} & \multirow[b]{2}{*}{13} & \multirow[b]{2}{*}{14} & \multirow[b]{2}{*}{15} & \multirow[b]{2}{*}{16} & \multirow[b]{2}{*}{17} & \multirow[b]{2}{*}{18} & \multirow[b]{2}{*}{19} & \multirow[b]{2}{*}{... } \\
\hline & & & & & & & 9 & 10 & 11 & & & & & & & & & \\
\hline $\begin{array}{l}\text { no region is on } \\
\text { holidays }\end{array}$ & $(0 ; 0)$ & $x$ & $x$ & $x$ & & & & $x$ & $x$ & $x$ & $x$ & $x$ & & & & $x$ & $x$ & $x$ \\
\hline $\begin{array}{l}\text { region of } \\
\text { residence z only } \\
\text { is on holidays }\end{array}$ & $(1 ; 0)$ & & & $x$ & $x$ & & $x$ & $x$ & & & & $x$ & $x$ & & $x$ & $x$ & & \\
\hline $\begin{array}{l}\text { other regions -z } \\
\text { only are on } \\
\text { holidays }\end{array}$ & $(0 ; 1)$ & & & $x$ & $x$ & $x$ & $x$ & $x$ & & & & $x$ & $x$ & $x$ & $x$ & $x$ & & \\
\hline $\begin{array}{l}\text { both } z \text { and } \\
\text { another region }-z \\
\text { are on holidays }\end{array}$ & $(1 ; 1)$ & & & & $x$ & $x$ & $x$ & & & & & & $x$ & $x$ & $x$ & & & \\
\hline
\end{tabular}

Note : For weeks 7, 9, 15 or 17, we observe for each region $z$ an alternation of years where both own region $z$ and another region $-z$ are on holidays, years where $z$ only is on holidays and years where other regions only are on holidays. For weeks 8 and 16, we observe an alternation of years where both region of residence $z$ and another region $-z$ are on holidays and years where only other regions $-z$ are on holidays. for weeks $6,10,14$ and 18 , we observe for each region $z$ an alternation of years where own region $z$ only is on holidays, years where another region $-z$ only is on holidays and years where no region is on holidays. 
Table A2 - Balancing test (LFS samples)

\begin{tabular}{lll}
\hline \hline & Mean & $\begin{array}{c}\text { School holiday } \\
\text { effect }\end{array}$ \\
\hline $\begin{array}{l}\text {-Sample of workers with children } \\
\text { 6-17 (N=168,620) }\end{array}$ & .496 & $+.001(.003)$ \\
Men & .419 & $+.005(.004)$ \\
At least high-school & .353 & $+.000(.005)$ \\
Age less than 40 & .777 & $+.002(.003)$ \\
Private sector & .218 & $-.000(.003)$ \\
Part-time & .893 & $-.003(.003)$ \\
Couple with children & 247 & $-0.3(4.1)$ \\
Number obs. per week & & \\
Sample of workers without & & \\
children (N=184,671) & .501 & $+.004(.003)$ \\
Men & .472 & $-.001(.004)$ \\
At least high-school & .420 & $+.008(.004) * *$ \\
Age less than 40 & .773 & $+.004(.003)$ \\
Private sector & .156 & $+.001(.003)$ \\
Part-time & .610 & $-.001(.004)$ \\
Couple w/o children & 239 & $+1.7(3.7)$ \\
Number obs. per week & & \\
\hline \hline
\end{tabular}

Note: Samples with and without children are the same as those used in Table 1. For each sample and each variable, the first column provides the sample mean whereas the second column provides the estimated variation in the mean across observations made within school holidays and observations made outside school holidays. Standard errors clustered at the household level are reported in parentheses. Source: French LFS, 2003-2011, INSEE. 
Table A3 - Commuter versus non-commuters

\begin{tabular}{lcc}
\hline \hline & $\begin{array}{c}\text { Non } \\
\text { commuters }\end{array}$ & Commuters \\
\hline Workers with children 6-17 & & \\
\% men & 48.8 & 68.2 \\
\% high-school degree & 41.6 & 48.7 \\
\% age less than 40 & 35.3 & 34.3 \\
\% part-time workers & 22.2 & 12.7 \\
\% private sector & 77.3 & 85.9 \\
\% in couple & 89.1 & 93.5 \\
Number of obs. & 155,223 & 6,537 \\
\hline Workers w/o children & & \\
\% men & 49.5 & 64.4 \\
\% high-school degree & 46.9 & 54.2 \\
\% age less than 40 & 42.0 & 41.6 \\
\% part-time workers & 15.8 & 9.8 \\
\% private sector & 77.1 & 83.7 \\
\% in couple & 60.9 & 64.7 \\
Number of obs. & 169,184 & 6,476 \\
\hline
\end{tabular}

Note: The sample includes employees observed between weeks 2 and 25, excluding those who are in the national education (or whose spouse, if any, is in the national education) as well as those with two or less months of seniority. 
Table A4 - Balancing tests (TUS samples)

\begin{tabular}{lcc}
\hline \hline Mean & $\begin{array}{c}\text { School holiday } \\
\text { effect }\end{array}$ \\
\hline $\begin{array}{l}\text { Workers with children 6- } \\
17 \text { (N=1,640) }\end{array}$ & & \\
Men & .507 & $-.003(.028)$ \\
At least high-school & .404 & $-.037(.044)$ \\
Age less than 40 & .434 & $-.030(.049)$ \\
Private sector & .740 & $+.041(.040)$ \\
Part-time & .219 & $+.023(.031)$ \\
Couple with children & .918 & $+.017(.025)$ \\
Number obs. per week & 23 & $-1.9(3.9)$ \\
& & \\
Workers without children & & \\
(N=1,873) & & \\
Men & .499 & $+.010(.031)$ \\
At least high-school & .481 & $-.034(.037)$ \\
Age less than 40 & .393 & $+.019(.040)$ \\
Private sector & .733 & $+.003(.035)$ \\
Part-time & .166 & $-.046(.029)$ \\
Couple w/o children & .607 & $-.005(.041)$ \\
Number obs. per week & 44 & $-0.3(8.3)$ \\
\hline
\end{tabular}

Note: Samples with and without children are the same as those used in Table 3. For each sample and each variable, the first column provides the sample mean whereas the second column provides the estimated variation in the mean across observations made within school holidays and observations made outside school holidays. Standard errors clustered at the household level are reported in parentheses. Source: French Time Use Surveys, 1999 and 2010, INSEE. 
Table A5 - School holidays and hours worked

\begin{tabular}{lccccc}
\hline & \multicolumn{2}{c}{ Employees with children 6-17 } & & \multicolumn{2}{c}{ Employees w/o children } \\
\cline { 2 - 3 } \cline { 5 - 6 } School holidays in & $(1)$ & $(2)$ & & $(3)$ & $(4)$ \\
\cline { 2 - 3 } \cline { 5 - 6 } region of residence & $-7.47^{* *}$ & $-7.48^{* *}$ & & $-2.19^{* *}$ & $-2.16^{* *}$ \\
& $(0.15)$ & $(0.15)$ & & $(0.14)$ & $(0.13)$ \\
School holidays in & $-0.78^{* *}$ & $-0.80^{* *}$ & & $-1.17^{* *}$ & $-0.98^{* *}$ \\
another region & $(0.17)$ & $(0.16)$ & & $(0.16)$ & $(0.15)$ \\
& & & & & \\
Add. controls & no & yes & & no & yes \\
Obs. & 161,760 & 161,760 & & 175,660 & 175,660 \\
Mean dep. var. & 31.64 & 31.64 & & 31.56 & 31.56 \\
\hline \hline
\end{tabular}

Notes: The sample includes employees observed between weeks 2 and 25, excluding those with two or less months of seniority as well as those who are in the national education (or whose spouse, if any, is in the national education). Columns (1) and (2) refer to the subsample with children aged 6-17 whereas columns (3) and (4) refer to the subsample without children. The table shows the results from reduced-form regressions in which the number of hours worked during week $w$, in year $t$ and region $z$ is regressed on a dummy indicating that $w$ corresponds to school holidays in $z$ and $t$, a dummy indicating that $w$ corresponds to school holidays in another region in year $t$. Control variables in columns 1 and 3 include 20 region dummies, 23 week dummies, 8 year dummies. Additional controls in columns 2 and 4 include dummies for gender, education level (5 dummies), private sector, part-time work, age (4 dummies) and industry (10 dummies). Standard errors clustered at the household level are reported in parentheses. Source: French LFS, 2003-2011, INSEE. 
Table A6 - School holidays and weeks off, by demographic subgroups

\begin{tabular}{|c|c|c|c|c|}
\hline & \multicolumn{2}{|c|}{ Single } & \multicolumn{2}{|c|}{ Couple without children } \\
\hline & Age $<40$ & Age $>40$ & Age $<40$ & Age $>40$ \\
\hline \multirow[t]{4}{*}{ Women } & $.056^{* *}$ & $.075^{* *}$ & $.036 * *$ & $.088 * *$ \\
\hline & $(.010)$ & $(.010)$ & $(.009)$ & $(.007)$ \\
\hline & $m=.095$ & $m=.118$ & $m=.123$ & $m=.120$ \\
\hline & $n=13,701$ & $n=18,535$ & $n=20,104$ & $n=35,389$ \\
\hline \multirow[t]{4}{*}{ Men } & $.037^{* *}$ & $.062^{* *}$ & $.017 * *$ & $.044^{* *}$ \\
\hline & $(.008)$ & $(.009)$ & $(.007)$ & $(.007)$ \\
\hline & $m=.087$ & $m=.107$ & $m=.081$ & $m=.114$ \\
\hline & $n=18,803$ & $n=17,466$ & $n=21,076$ & $n=30,586$ \\
\hline
\end{tabular}

Notes: The table shows the results of replicating the same reduced form regression as in Table 1 on various subsamples of workers without children, defined by workers' age (above/below age 40) as well as by household's type (couple/single). Each cell of the Table corresponds to one specific subsample and for each subsample we report the effect of school holidays in region of residence, as well as the mean of the dependent variable $(m)$ and the number of observations $(n)$ in the subsample. Standard errors clustered at the household level are reported in parentheses. Source: French LFS, 2003-2011, INSEE. 
Table A7 - School holidays and weeks off, by seniority and industry

\begin{tabular}{|c|c|c|}
\hline & $\begin{array}{c}\text { Workers with } \\
\text { children 6-17 } \\
\text { (1) }\end{array}$ & $\begin{array}{l}\text { Workers w/o } \\
\text { children } \\
\text { (2) }\end{array}$ \\
\hline \multicolumn{3}{|l|}{ - Seniority } \\
\hline More than one year & $\begin{array}{l}.191 * * \\
(.004)\end{array}$ & $\begin{array}{l}.056^{* *} \\
(.003)\end{array}$ \\
\hline One year or less & $\begin{array}{l}.101^{* *} \\
(.010)\end{array}$ & $\begin{array}{l}.039 * * \\
(.008)\end{array}$ \\
\hline \multicolumn{3}{|l|}{ - Industry } \\
\hline Manufacturing industries & $\begin{array}{l}.144^{* *} \\
(.007)\end{array}$ & $\begin{array}{l}.024^{* *} \\
(.006)\end{array}$ \\
\hline Construction; agriculture & $\begin{array}{l}.093^{* *} \\
(.009)\end{array}$ & $\begin{array}{l}.028 * * \\
(.011)\end{array}$ \\
\hline $\begin{array}{l}\text { Wholesale and retail trade; repair of } \\
\text { motor vehicles and motorcycles }\end{array}$ & $\begin{array}{l}.159 * * \\
(.009)\end{array}$ & $\begin{array}{l}.015^{*} \\
(.008)\end{array}$ \\
\hline Transportation and storage & $\begin{array}{l}.155^{* *} \\
(.014)\end{array}$ & $\begin{array}{l}.044^{* *} \\
(.013)\end{array}$ \\
\hline Financial and insurance activities & $\begin{array}{l}.280 * * \\
(.019)\end{array}$ & $\begin{array}{l}.042^{* *} \\
(.015)\end{array}$ \\
\hline Real estate activities & $\begin{array}{l}.175 * * \\
(.029)\end{array}$ & $\begin{array}{l}.037^{*} \\
(.020)\end{array}$ \\
\hline Other service activities & $\begin{array}{l}.152 * * \\
(.008)\end{array}$ & $\begin{array}{l}.042 * * \\
(.006)\end{array}$ \\
\hline $\begin{array}{l}\text { Public administration, defence, } \\
\text { education, health and social work. }\end{array}$ & $\begin{array}{l}.256^{* *} \\
(.007)\end{array}$ & $\begin{array}{l}.102 * * \\
(.006)\end{array}$ \\
\hline
\end{tabular}

Notes: The table shows the results of replicating the same reduced form regression as in Table 1 on various subsamples defined by workers' seniority level (less/more than one year) and workers' industry. Column 1 refers to the sample of workers with children aged 6-17 whereas column 2 refers the sample without children. Top panel shows results for the different subsamples defined by seniority level whereas the bottom panel further focuses on workers with more than one year of seniority and shows results for the different subsamples defined by industry. Each cell of the Table corresponds to a specific regression and for each regression we report the main effect of school holidays only. Standard errors clustered at the household level are reported in parentheses. Source: French LFS, 2003-2011, INSEE. 
Table A8 - School holidays and vacation trips, by income groups

\begin{tabular}{|c|c|c|c|c|}
\hline \multirow{2}{*}{$\begin{array}{l}\text { Panel A: employees } \\
\text { w/o children }\end{array}$} & All & \multicolumn{3}{|c|}{ Accomodation } \\
\hline & (1) & $\begin{array}{c}\text { Holiday home } \\
(2)\end{array}$ & $\begin{array}{l}\text { Family/friends } \\
\text { (3) }\end{array}$ & $\begin{array}{l}\text { Rental } \\
(4)\end{array}$ \\
\hline \multirow{4}{*}{ Low income } & .009 & .000 & .008 & .001 \\
\hline & $(.008)$ & $(.000)$ & $(.006)$ & $(.005)$ \\
\hline & $m=.020$ & $m=.000$ & $m=.011$ & $m=.007$ \\
\hline & $n=10,080$ & $n=10,080$ & $n=10,080$ & $n=10,080$ \\
\hline \multirow[t]{4}{*}{ Middle income } & .011 & .000 & $.009 * *$ & -.001 \\
\hline & $(.008)$ & $(.001)$ & $(.004)$ & $(.007)$ \\
\hline & $m=.021$ & $m=.001$ & $m=.008$ & $m=.011$ \\
\hline & $n=9,000$ & $n=9,000$ & $n=9,000$ & $n=9,000$ \\
\hline \multirow[t]{4}{*}{ High income } & $.030 * *$ & .004 & $.013^{* *}$ & $.013^{*}$ \\
\hline & $(.010)$ & $(.003)$ & $(.006)$ & $(.007)$ \\
\hline & $m=.038$ & $m=.004$ & $m=.011$ & $m=.021$ \\
\hline & $n=14,832$ & $n=14,832$ & $\mathrm{n}=14,832$ & $n=14,832$ \\
\hline \multirow[t]{2}{*}{ Panel B : retirees } & All & & Accomodation & \\
\hline & (1) & $\begin{array}{c}\text { Holiday home } \\
\text { (2) }\end{array}$ & $\begin{array}{l}\text { Family/friends } \\
\text { (3) }\end{array}$ & $\begin{array}{l}\text { Rental } \\
(4)\end{array}$ \\
\hline \multirow[t]{4}{*}{ Low income } & .004 & -.001 & .003 & .002 \\
\hline & $(.004)$ & $(.001)$ & $(.004)$ & $(.003)$ \\
\hline & $m=.017$ & $m=.000$ & $m=.001$ & $m=.006$ \\
\hline & $n=18,144$ & $n=18,144$ & $n=18,144$ & $n=18,144$ \\
\hline \multirow[t]{4}{*}{ Middle income } & .008 & $.007^{* *}$ & -.001 & .003 \\
\hline & $(.008)$ & $(.003)$ & $(.005)$ & $(.006)$ \\
\hline & $m=.047$ & $m=.008$ & $m=.017$ & $m=.021$ \\
\hline & $n=14,712$ & $n=14,712$ & $n=14,712$ & $n=14,712$ \\
\hline \multirow[t]{4}{*}{ High income } & $.047^{* *}$ & $.027^{* *}$ & .007 & $.013^{* *}$ \\
\hline & $(.012)$ & $(.008)$ & $(.007)$ & $(.006)$ \\
\hline & $m=.066$ & $m=.020$ & $m=.011$ & $m=.025$ \\
\hline & $\mathrm{n}=18,360$ & $n=18,360$ & $\mathrm{n}=18,360$ & $n=18,360$ \\
\hline
\end{tabular}

Note: The table shows the results of replicating the same reduced form regressions as in Table 4 and 5 on various subsamples of workers without children (panel A) or retirees (panel B) defined by income terciles. Each cell of the table corresponds to a specific subsample and for each specific subsample we report the effect of school holidays in region of residence as well as the mean of the dependent variable $(\mathrm{m})$ and the number of observation in the subsample. Standard errors clustered at the household level are reported in parentheses. Source: Vacation Trip Survey, 2004, INSEE. 
Table A9 - School holidays and vacation trips: the case of unemployed workers

\begin{tabular}{lccc}
\hline \hline & All & $\begin{array}{c}\text { High-school } \\
\text { graduates }\end{array}$ & $\begin{array}{c}\text { High-school } \\
\text { dropout }\end{array}$ \\
\cline { 2 - 4 } $\begin{array}{l}\text { Unemployed with } \\
\text { school-age children }\end{array}$ & $\begin{array}{l}.036^{* *} \\
(.012)\end{array}$ & $\begin{array}{c}.127^{* *} \\
(.042)\end{array}$ & .011 \\
& $\mathrm{~m}=.018$ & $\mathrm{~m}=.016$ & $(.009)$ \\
& $\mathrm{n}=3,792$ & $\mathrm{n}=578$ & $\mathrm{~m}=.016$ \\
Unemployed w/o & .005 & & $\mathrm{n}=3,000$ \\
children & $(.009)$ & $.023^{* *}$ & -.008 \\
& $\mathrm{~m}=.018$ & $(.010)$ & $(.012)$ \\
& $\mathrm{n}=5,376$ & $\mathrm{~m}=.010$ & $\mathrm{~m}=.017$ \\
& & $\mathrm{n}=2,064$ & $\mathrm{n}=3,312$ \\
\hline \hline
\end{tabular}

Note: The table shows the results of replicating the same reduced form regressions as in Table 4 and 5 on various subsamples of unemployed workers with and without children defined by education level. Each cell of the table corresponds to a specific subsample and for each specific subsample we report the effect of school holidays in region of residence as well as the mean of the dependent variable $(\mathrm{m})$ and the number of observation in the subsample. Standard errors clustered the household level are reported in parentheses. Source: Vacation Trip Survey, 2004, INSEE. 


\section{Appendix B}

\section{A Time Use Model}

We consider an economy where workers are entitled to a fixed amount $(m)$ of paid leave per time interval $t$. Also, we assume that each time interval $t$ includes a school break. For each $t$, we denote $L_{0 t}$ the amount of vacation time taken outside school holidays and $L_{1 \mathrm{t}}$ the amount of vacation time taken within school holidays. By construction, we have,

(1) $L_{0 \mathrm{t}}+L_{1 \mathrm{t}} \leq \mathrm{m}$.

For the sake of simplicity, we assume that the behavior of workers with school-age children is exogenously set: they take their paid leave during school holidays only. We focus on the time use decisions of workers without children. For each $t$, they chose their level of consumption $C_{\mathrm{t}}$ as well as the chronicle of their holidays $L_{\mathrm{t}}=\left(L_{0 \mathrm{t}}, L_{1 \mathrm{t}}\right)$ in order to maximize a utility function $U_{t}\left(C_{t}, L_{t}\right)$ which is assumed linear-quadratic as in Brock and Durlauf (1995),

(2) $\mathrm{U}_{\mathrm{t}}\left(C_{\mathrm{t}}, L_{0 \mathrm{t}}, L_{1 \mathrm{t}}\right)=\varphi C_{\mathrm{t}}+\left(\varepsilon_{0 \mathrm{t}}+\sigma \underline{L}_{0 \mathrm{t}}\right) L_{0 \mathrm{t}}-\mathrm{b} L_{0 \mathrm{t}}{ }^{2} / 2+\left(\varepsilon_{1 \mathrm{t}}+\sigma \underline{L}_{1 \mathrm{t}}\right) L_{1 \mathrm{t}}-\mathrm{b} L_{1 \mathrm{t}}{ }^{2} / 2$

where $\underline{L}_{0 t}\left(\underline{L}_{1 \mathrm{t}}\right)$ represents overall proportion of workers on vacation outside (within) school holidays while $\varepsilon_{0 \mathrm{t}}$ and $\varepsilon_{1 \mathrm{t}}$ captures seasonal shocks to the utility of being on holidays (climatic shocks for instance). Parameter $\sigma$ represents a taste-for-conformity parameter. The problem is to maximize $U_{t}$ under condition (1) and the following budget constraint,

(3) $C_{\mathrm{t}}+\mathrm{p}_{0 \mathrm{t}} L_{\mathrm{tot}}+\mathrm{p}_{1 \mathrm{t}} L_{\mathrm{t} 1 \mathrm{t}} \leq R_{\mathrm{t}}$

where $R_{\mathrm{t}}$ represents income while $\mathrm{p}_{\mathrm{ot}}\left(\mathrm{p}_{1 \mathrm{t}}\right)$ represents the costs of vacation taken outside (within) school holidays. We assume that each $p_{k t}(k=0,1)$ is linearly dependent on the overall proportion of workers $\underline{L}_{k t}$ taking paid leave, and namely $p_{k t}=\alpha \underline{L}_{k t}+\beta$.

The first order conditions imply (after averaging across workers without children),

(4) $\left(\underline{L}_{1 n t}-\underline{L}_{0 n t}\right)=\theta\left(\underline{L}_{1 t}-\underline{L}_{0 t}\right)+\left(\varepsilon_{1 \mathrm{t}}-\varepsilon_{0 \mathrm{t}}\right)$,

where $\underline{L}_{\text {ont }}\left(\underline{L}_{1 n t}\right)$ represents the proportion of workers without children taking paid leave outside (within) school holidays vacation. Parameter $\theta=(\sigma-\varphi \alpha) / b$ captures how variation in overall demand for leisure affect those of workers without children. Parameter $\theta$ is proportional to $(\sigma-\varphi \alpha)$, and namely to the effect $\sigma$ of non-market interactions mitigated by the effect $\varphi \alpha$ of market-induced interactions. It can be rewritten,

(5) $\left(\underline{L}_{1 n t}-\underline{L}_{0 n}\right)=\beta\left(\underline{L}_{1 p t}-\underline{L}_{0 p t}\right)+\left(u_{1 t}-u_{0 t}\right)$, 
with $\beta=(1-\pi) \theta /(1-\pi \theta)$ and $u_{k t}=\varepsilon_{k t} /(1-\pi \theta)$, where $\pi$ is the share of workers without children in the population while $\underline{L}_{0 \mathrm{pt}}\left(\underline{L}_{1 \mathrm{pt}}\right)$ represents the proportion of workers with children taking paid leave outside (within) school holidays vacation.

In the French context, periods of school holidays are quasi randomly distributed across regions and years. Hence, the average value of $\varepsilon_{1 \mathrm{t}}-\varepsilon_{0 \mathrm{t}}$ over years or regions is negligible: given the quasi random distribution of school holidays' dates, there is on average no specific value associated with taking vacation leave within or outside school holidays. Hence, parameter $\beta$ can be identified by the ratio between the average ( $\left.\underline{L}_{1 n t}-\underline{L}_{0 n}\right)$ and the average $\left(\underline{L}_{1 p t}-\underline{L}_{0 p t}\right)$. 